\title{
Nem szteroid gyulladáscsökkentők peroralis és transdermalis alkalmazása regionális mozgásszervi fájdalmi szindrómákban
}

\author{
Hodinka László dr. ${ }^{1}$ - Bálint Géza dr. ${ }^{1}$ - Budai Erika dr. ${ }^{2}$ \\ Géher Pál dr. ${ }^{3}$ - Papp Renáta $\mathrm{dr}^{4}{ }^{4}$ - Somogyi Péter $\mathrm{dr} .^{5}$ \\ Szántó Sándor dr. ${ }^{6}$. Vereckei Edit dr. ${ }^{1}$ \\ ${ }^{1}$ Országos Reumatológiai és Fizioterápiás Intézet, Budapest \\ ${ }^{2} J a h n$ Ferenc Dél-pesti Kórház, Budapest \\ ${ }^{3}$ Budai Irgalmasrendi Kórház, Semmelweis Egyetem, Általános Orvostudományi Kar, \\ III. Belgyógyászati Klinika, II. Tanszéki Csoport, Budapest \\ ${ }^{4}$ Magyar Általános Orvosok Tudományos Egyesülete, Budapest \\ ${ }^{5}$ Országos Sportegészségügyi Intézet, Budapest \\ ${ }^{6}$ Debreceni Egyetem, Általános Orvostudományi Kar, Belgyógyászati Intézet, Reumatológiai Tanszék, Debrecen
}

\begin{abstract}
A tanulmány szerzői a napi gyakorlatban a leggyakrabban fellépő mozgásszervi panaszok hátterében álló regionális fájdalmi szindrómák leggyakoribb kezelési módjával, a per os és transdermalisan alkalmazott nem szteroid gyulladáscsökkentőkkel végzett fájdalomcsillapításról rendelkezésre álló bizonyítékokat gyüjtötték össze. Azon szakterületeken múködők számára, akik leggyakrabban találkoznak az átmeneti és fájdalmas epizódokkal (háziorvosok, reumatológusok, ortopédek, foglalkozás-egészségügyi és sportorvosok), külön meghatározták a foglalkozási vagy sporttevékenységük (a mozgásszervek ismétlődő vagy nagy energiájú igénybevétele) miatt kockázatnak kitettek körét és ismertetik fájdalmaik patológiai magyarázatát. A fájdalomcsillapítás eszközei között részletezik a nem szteroid gyulladáscsökkentők hatásának módját és farmakológiai sajátosságait. Kiemelik a gyógyszeres kezelés kockázatait és az emiatt veszélyeztettek speciális csoportjait (gyermekkorúak és idősek). Az általános fájdalomcsillapítási alapelvek és stratégiák ismertetésén túlmenően a hazai és nemzetközi irányelvekből a tanulmány tárgyára vonatkozó ajánlásokat adják közre.
\end{abstract}

Orv Hetil. 2017; 158(Suppl. 3): 3-30.

Kulcsszavak: nem szteroid gyulladáscsökkentôk, regionális mozgásszervi fájdalmi szindrómák, mozgásszervi foglalkozási és sportbetegségek

\section{Peroral and transdermal application of non-steroidal anti-inflammatory drugs (NSAIDs) for the treatment of regional musculoskeletal pain syndromes}

\begin{abstract}
In this review the available evidences regarding the most frequently applied medication (peroral and transdermal non-steroidal anti-inflammatory agents) for the most frequent musculoskeletal complaints (regional pain syndromes) have been collected for the appropriate medical professionals who are most frequently faced with these conditions (general practitioners, rheumatologists, orthopedics, occupational and sports medicine experts). The special population at risk (with repeated and high energy overuse because of occupational or sport activities) and the pathology of their syndromes are identified. Mode of action, pharmacological properties of the non-steroidal anti-inflammatory drugs and the unwanted effects of their application especially in infants and elderly are highlighted. Recommendations of the general and specific pain management guidelines have been selected and listed in the review.
\end{abstract}

Keywords: non-steroidal anti-inflammatory drugs, regional musculoskeletal pain syndromes, musculoskeletal occupational and sport diseases 
Hodinka L, Bálint G, Budai E, Géher P, Papp R, Somogyi P, Szántó S, Vereckei E. [Peroral and transdermal application of non-steroidal anti-inflammatory drugs (NSAIDs) for the treatment of regional musculoskeletal pain syndromes]. Orv Hetil. 2017; 158(Suppl. 3): 3-30.

(Beérkezett: 2017. augusztus 10.; elfogadva: 2017. október 11.)

\section{Rövidítések}

$\mathrm{ACE}=($ angiotensin converting enzyme $)$ angiotenzinkonvertáló enzim; ACR = (American College of Rheumatology) Amerikai Reumatológiai Kollégium; AGREE = (Appraisal of Guidelines for Research and Evaluation) Kutatási és egészségügyi állapotfelmérési irányelvek értékelésének rendszere; ARB $=($ angiotensine receptor blocker $)$ angiontenzinreceptor-blokkoló; ASA = (acetylsalicylic acid $)$ acetilszalicilsav; BMI = (body mass index) testtömegindex; $\mathrm{COX}=($ cyclooxygenase $)$ ciklooxigenáz-gátló enzim, l-es és 2-es izotípus; $\mathrm{CV}=$ cardiovascularis; EMA $=($ European Medicines Agency $)$ Európai Gyógyszerügynökség; EP-4 = (prostanoid EP-4 receptor) prosztaglandin $E P-4$ receptor; $\mathrm{GABA}=$ (gamma-aminobutyric acid) gamma-aminovajsav; GRADE $=$ (Grading of Recommendations Assessment Development and Evaluation) Egészségügyi állapotfelmérési, ellátásfejlesztési és -értékelési ajánlások súlyozási rendszere; IASP $=($ International Assotiation for the Study of Pain) Nemzetközi Fájdalomkutatási Társaság; IL-1 = (interleukine-1) interleukin- $1 ; \mathrm{MRI}=($ magnetic resonance imaging) mágneses rezonanciás diagnosztika; NGF = (nerve growth factor) idegnövekedési faktor; NSAID $=($ non-steroidal anti-inflammatory drug) nem szteroid gyulladáscsökkentő; OARSI $=$ (Osteoarthritis Research Society International) Nemzetközi Osteoarthrosis Kutatási Társaság; OTC $=$ (over the current) nem receptköteles; PG $=$ (prostaglandin) prosztaglandin; PGE-2 = prosztaglandin-E2; PGI-2 = prosztaglandin-I2; PPI = (proton pump inhibitor) protonpumpagátló; PRINTO $=($ Pediatric Rheumatology International Trials Organisation) Gyermekreumatológiai Nemzetközi Klinikai Gyógyszervizsgálati Szervezet; RICE = (rest, ice, compression, elevation) nyugalomba helyezés, jegelés, nyomókötés, felpolcolás módszere; SIJ = (sacroiliac joint $)$ sacroiliacalis ízület; SSRI = (selective serotonin reuptake inhibitor $)$ szelektív szerotoninvisszavétel-gátló; TDDS = (transdermal drug delivery system) bőrfelszínről történő gyógyszerbevitel technológiai eljárás; TENS $=$ (transcutaneous electrical nerve stimulation) bőrfelszínrôl történő elektromos idegingerlés módszere; TNS $=$ (tumor necrosis factor $)$ tumornekrózis-faktor; $\mathrm{UH}=$ ultrahangvizsgálat; UV-A = (ultraviolet-A) ultraibolya-A-sugárzás; WADA = (World Anti-Doping Agency) Doppingellenes Világszervezet

A tanulmány célja, hogy kijelölje a peroralisan és transdermalisan alkalmazható nem szteroid gyulladáscsökkentők helyét a mozgásszervi betegségeket ellátó szakágak napi klinikai gyakorlata során a leggyakrabban megjelenő regionális mozgásszervi fájdalmak gyógyszeres terápiájában. Ennek érdekében bemutatja az alkalmazási területeket, a készítmények hatásainak és nem kívánt hatásainak mechanizmusát, az alkalmazásuktól elvárható eredményeket és mérlegelendő kockázatokat. Ezeket a vonatkozó szakirodalom és korábban közreadott irányelvek fényében értékelve ajánlásokat fogalmaz meg. A szerzők évtizedes szakmai és vezetői tapasztalattal rendelkeznek az aneszteziológia és intenzív terápia, a belgyógyászat, a háziorvostan, a klinikai farmakológia, az ortopédia, a mozgásszervi rehabilitáció és a reumatológia szakterületén. Az ajánlások bizonyítékait és erősségét saját értékelésük, a korábbi irányelvekben és metaanalízisekben közreadott súlyozás alapján adják meg. Az ajánlások véglegesítéséhez a Delphi módszert [1], a súlyozáshoz és a tanulmány szerkesztéséhez a GRADE [2, 3] és az AGREE [4] nemzetközi rendszereket alkalmazták a szerkesztés és belső auditálás során. A tanulmány nem tárgyalja részletesen a neuropathiás és centrális fájdalmakat, a szteroidok, opiátok, opioidok, antipszichotikumok és hagyományos analgetikumok alkalmazását. Ezeket olyan mértékig ismertetjük, amely a nem szteroid gyulladáscsökkentőknek a terápiás fegyvertárban elfoglalt helyének bemutatásához szükséges. Invazív beavatkozások, ideértve a szisztémás parenteralis és lokális injekciós gyógyszeralkalmazásokat, szintén nem képezik a tanulmány tárgyát. Elismerve a betegtájékoztatás, -felvilágosítás és a nem gyógyszeres fájdalomcsillapítás alapvető jelentőségét és fontosságát, a tanulmány csupán a nem szteroidok peroralis és transdermalis alkalmazásának pozicionálása kapcsán említi a kiegészítő és alternatív fájdalomcsillapítási eljárásokat.

\section{Az alkalmazás szakmai célcsoportjai}

A tanulmány és a megfogalmazott ajánlások az általános orvosok, az aneszteziológia és intenzív terápia, a belgyógyászat, a foglalkozás-egészségügy, a háziorvostan, a klinikai farmakológia, az ortopédia és traumatológia, a mozgásszervi rehabilitáció, a reumatológia és a sportorvostan szakterületén múködő szakorvosok, gyógytornász-fizioterapeuták és a mozgásszervi betegeket ellátó más, nem orvos szakemberek és szakdolgozók számára kíván tájékoztatást nyújtani.

\section{A nociceptív fájdalom és a nem szteroid gyulladáscsökkentők hatásmechanizmusa}

A fájdalominger sérülés, betegség vagy feldolgozási zavar következményeként, az érzőneuronok közvetítésével a központi idegrendszerben összetett kellemetlen érzésként jelentkezik, amely elhárítómechanizmusokat vált ki. $\mathrm{Az}$ akut fájdalom fiziológiás, funkciója figyelmeztetés. A krónikus fájdalom folyamatos inger révén tartósan 
fennmarad, értelmezhető funkciója a kóros folyamat monitorozása, mindig patológiás.

Karaktere és mechanizmusa szerint lehet nociceptív (perifériás szövetsérülés, gyulladás váltja ki), neuropathiás (a neuron sérülése, anyagcsere-változása indukálja), kevert nociceptív és neuropathiás, valamint pszichogén (a központi idegrendszeri integráció és feldolgozás zavara). Ez utóbbi a centrális fájdalom, ami stresszre vagy kórosan felfokozott fájdalomingerre adott patológiás pszichés és viselkedési válasz, „fájdalomviselkedés”. A centrális fájdalomra predesztináló fenotípus: női nem, fiatalkori trauma, genetikai háttér, krónikus fájdalom és viselkedészavar a családban és a betegben. Ilyenek a központi idegrendszer közvetítette krónikus tünetek: diffúz neuropathiás fájdalom, fáradékonyság, alvászavar, pszichés zavar, emlékezetzavar, „katasztrofizálási” élmények. Alapja az alacsony mechanikai fájdalomküszöb és csökkent fájdalomgátlási képesség, amelyet aktuális stressz vagy akut nociceptív fájdalom tartóssá válása vált ki [5-8].

A nociceptív receptorok elsődleges ingerei az energiaközlés és az aciditás. A patogének és a szövetsérülésből származó molekulák a gyulladásos hírvivők kaszkádját indítják meg, amely megsokszorozza a primer ingert a nociceptoron. A szöveti sérülés és gyulladás fájdalomingert keltő anyagai a veszélyjelző és patogén jelzőmolekulák. Ezek általános aktiváló citokineket szabadítanak fel (IL-1, TNF). A degranulálódó hízósejtekből aminok (hisztamin, szerotonin), kininek (bradikinin, neurokinin), neuropeptidek (substance $\mathrm{P}$, neurokinin), az aktiválódó makrofágokból a citokinindukált COX-2 által szintetizált prosztanoidok (PG) és idegnövekedési faktor (NGF) szabadulnak fel. Ezek az elsőrendü neuronon lévő receptoraikhoz kötődnek. A tartós fájdalominger érzékenyíti a nociceptort (perifériás szenzitizáció). Az elsődleges neuron a hátsógyökér-ganglion, axonja a gerincvelő hátsó szarvában a másodrendû neuronra kapcsolódik. Ennek axonja az ellenkező oldalon halad a thalamusig, kapcsolatban áll a basalis ganglionokkal, amygdalával. A fájdalominger az agykéreg különböző mezőibe vezetődik [7-10].

A perifériás szenzitizáció csökkenti a nociceptor ingerküszöbét. A neuron gerincvelői terminálján fájdalomkeltő neurotranszmitterek szabadulnak fel, amelyek a gerincvelő hátsó szarvi neuronját érzékenyítik. Ez a centrális szenzitizáció, amelynek lényege: az alacsony küszöbű nociceptor-input, az ingerlékenység fokozódása a hátsó szarv neuronjaiban és az ezek következtében megváltozott válaszkészség és nagyobb fájdalomérzet (allodynia és hyperalgesia). A krónikus fájdalom okozta szenzitizáció a centrális fájdalom alapja.

A szenzitizáció központi mediátora a prosztaglandinE2, amelyet a periférián és a központi idegrendszerben a részben konstitutív, részben indukálható COX-2 enzim szintetizál. A PGE-2 számos, G-proteinnel kapcsolt receptoron kötődik, a célsejtben az adenilát-cikláz enzimet aktiválja, a keletkező ciklikus AMP a proteinkináz enzim útján általános stimulációt indít meg. A PGE-2 és EP-4 receptora ezért ígéretes terápiás célpont $[9,11,12]$.

A fájdalomérzés színezetét az inger ereje, az értelmezés, az érzelmek befolyásolják. A kellemetlen karaktert a prefrontális, frontális és insularis kéreg társítja. Ez határozza meg a fájdalmi kedélyállapotot. A leszálló módosító pályák neuronjai a középagy, az agytörzs és a gerincvelő hátsó szarvának neuronjain fejtik ki gátlóhatásukat. A legfontosabb fájdalomkeltő neurotranszmitter a glutamát (általános izgató neurotranszmitter, fokozza az ingerátadást az egész idegrendszerben). A fájdalomérzést gátló vagy módosító neurotranszmitterek a gamma-aminovajsav (GABA), amely általános gátló neurotranszmitter, gátolja a neuronok kisülését, a noradrenalin (a kedélyállapot és élénkség szabályozója, fokozza az éberséget és a veszélyérzékelést) és a szerotonin, amely az alvás, ébrenlét, éhség és agresszivitás szabályozója. Az endorfinok endogén fájdalomcsillapítók, amelyek az idegrendszer leszálló pályáinak átkapcsolási pontjain expresszálódó receptoraikon keresztül közvetett gátlóimpulzusokat indukálnak, fájdalomcsillapító és euforizáló hatást fejtenek ki. A neurotranszmitterek receptorai az elsődleges terápiás célpontok [8].

\section{A tanulmány által lefedett klinikai képek}

A mozgásszervekben jelentkező fájdalmi szindrómákat a napi gyakorlatban való előfordulásuk gyakorisága és a legtöbbször érintett régiók szerint tárgyaljuk. A legjellemzőbb nociceptív fájdalmak okait mutatjuk be részletesebben. Az ideggyöki, perifériás ideg-és érkompresszióval járó elváltozásokat neuropathiás és keringési komponenseik miatt nem tárgyaljuk. A reumatológiai gyulladásos rendszerbetegségek okozta gyulladásos fájdalmakat generalizált jellegük miatt nem érintjük a tanulmányban. A degeneratív ízületi és porckorong-károsodások okozta fájdalmakat a leggyakoribb regionális előfordulás és fokozott igénybevétel szerint említjük. A tanulmány a regionális fájdalmak kezelésére fókuszál. A kezelés megtervezéséhez azonban nélkülözhetetlen a fájdalom okának, eredetének a lehető legpontosabb azonosítása.

A fájdalom keletkezésének mechanizmusaira, a fájdalom típusaira vonatkozó alapismereteken túlmenően, a potenciálisan fájdalmas régiók anatómiájának és biomechanikájának mélyreható ismerete és a fájdalom kvalitásainak felismerésében szerzett tapasztalat is szükséges. Tájékozódnunk kell a beteg saját, fájdalmát kísérő szubjektív kommentárjait illetően is, és saját tapasztalatunk birtokában kell értékelnünk az általa interpretált fájdalomjellemzőket. Ezt az interpretációt kell súlyozni és a fizikális vizsgálatra támaszkodva ki kell egészíteni a nyomásérzékenységból és az anatómiai ismeretek birtokában célzottan kiváltott fájdalomból nyerhető információkkal.

A leggyakoribb nociceptív fájdalmak közé tartoznak az inhüvelyek, izom-és intapadási helyek túleröltetése által okozott betegségek, közöttük is az enthesitisek, az inak és 
szalagok eredési-tapadási helyeinek gyulladásai. Ez az elváltozás ott jelentkezik, ahol a kötőszövetnek mozgáskitérést szabályozó szerepe van. Túlterhelés során az érintett kötőszövet degenerálódik, a periosteum sejtjeinek aktivitása csontképződést, a szalagtapadási helyen elcsontosodást eredményezhet. Enthesopathia oka lehet a lokális krónikus túlterhelés, például számítógép-használat, egerezés vagy rövid ideig tartó szokatlan terhelés, mint a hólapátolás. Az anamnézis ismeretében sok esetben már a fizikális vizsgálattal (az enthesitisre jellemző fájdalom passzív nyújtással, illetve a passzív ellenállással szemben végzett mozgással provokálható) is kimondható a diagnózis. Pontosabb kórismézéshez UH-, röntgenvagy MR-vizsgálat javasolt. Régen lezajlott, illetve ismétlődő enthesitisek lokális meszesedéshez vezethetnek, amely röntgennel is kimutatható. A leggyakoribb enthesitisek: epicondylitis lateralis humeri (az úgynevezett teniszkönyök) és az epicondylitis medialis humeri (az úgynevezett golfkönyök). Mindkettő a felső végtagot terhelő tevékenység által provokált betegség.

Az inak és inhüvelyek gyulladása a tendinitis és tenosynovitis. Elsősorban az ínhüvely synovialis hártyáján, kisebb részben az ínban zajló akut vagy krónikus gyulladás esetében beszélünk tendinitisről vagy tenosynovitisről. Az etiológiai tényező körében túlterhelés, folyamatos mikrotraumák említhetók meg. A tendinitisek leggyakoribb lokalizációja a váll rotátorköpenye, a kéz- és ujjhajlítók, illetve -feszítők, a lábfeszítő izmok inai és az Achilles-ín. Lokális nyomásérzékenység, duzzanat, melegebb tapintat lehet az ín felett. Krónikus gyulladás esetén crepitatio is észlelhető. A diagnózis többnyire a fizikális vizsgálat alapján is kimondható. Ultrahang- vagy MRvizsgálattal az ín megvastagodása és az ínhüvelyben gyulladásos folyadékszaporulat látható. Krónikus szakban a röntgenfelvétel meszesedést mutathat $[13,14]$.

A váll, mint szabad ízület, kiterjedt mozgásait a rotátorköpeny anatómiai felépítése biztosítja. Éppen a megkívánt nagy mozgásterjedelem és a mozgáshoz társuló nyomaték és erókifejtés igénye miatt gyakori a köpenyt alkotó inak, szalagok tendinitise, rupturája. A rotátorköpeny érintettségének leggyakoribb lokalizációja a musculus supraspinatus ina. Ennek károsodását fóleg mikrotraumák, az erókifejtés alatti ismétlődő vongálódás okozhatják. A supraspinatus ín érintettségének jellegzetes klinikai tünete a „középsőív-szindróma”. A fizikális vizsgálat során a beteg a kar abdukciója, elevációja során a középső ívben, azaz 30-60 fok között jelez fájdalmat. A supraspinatus ín rupturájának jellegzetes tünete, hogy a kar aktív abdukciója $0-30^{\circ}$ között nem vihető ki. Ritkábban előfordulhat más, rotátorköpenyt alkotó ín szakadása is, például a musculus subscapularisé. A fizikális vizsgálaton túl a supraspinatus ín rupturájának gyanúja esetén röntgen-, UH-, illetve MR-vizsgálat javasolt. A pontos diagnózis különösen fontos friss ruptura esetén az esetleges ortopédiai-traumatológiai beavatkozás szempontjából $[13,14]$.
A vállízület egyik leggyakoribb betegsége az impingement szindróma. Ilyenkor a vállcsúcs alatti anatómiai tér - előzetes nagyobb vagy ismétlődő mikrotrauma és a rendszerint következményes gyulladás miatt - beszúkül, és a rotátorköpeny minden egyes felkarmozdulat során becsípődik a vállcsúcs és a felkarcsont közé. Ez súlyos, egyre erősödő fájdalmat vált ki. A leggyakrabban túlerőltetés után alakulnak ki a panaszok, gépkocsivezetőknél gyakori. A fizikális vizsgálat alapján nem mindig egyértelmû a diagnózis, röntgen, UH- és MR-vizsgálat végzése javasolt. A röntgenfelvételen a humerusfej felfelé csúszik, az acromionba ütközhet. Ezen jelek alapján gondolhatunk a diagnózisra.

A rotátorköpeny további eltéréseinek pontos megítéléséhez UH-, illetve fóleg MR-vizsgálat szükséges [13, 14]. A vállízület fájdalmas instabilitásának jellegzetes képalkotó lelete a Hill-Sachs-, illetve a Bankart-laesio. Gyakori, váll körüli fájdalmas jelenség a biceps-tendinitis. A biceps-tendinitis a musculus biceps brachii hosszú fejének inát érintő gyulladás. A musculus biceps brachii az alkart supinálja. A biceps-tendinitis a hosszú fej inának eredésétől az izomhasba való átmenet közötti sérülés miatt alakul ki. Leggyakoribb oka az úgynevezett impingement tendinitis, amely a vállízületi impingement szindróma része lehet. Lényege, hogy a rotátorköpeny nyújtotta védettség megszúnik, a kar emelésével az acromion az inat sérti, a mozdulatsor ismétlődésével alakul ki a kórkép. Az alapvető etiológiai tényező a túlterhelés. Az említett, vállízület körüli eltérésekhez hasonlóan a fizikális, UH-, MR-vizsgálat segíthet a kórismézésben. Fizikális vizsgálat során Speed-teszt (a nyújtott, tenyérrel felfelé néző kart a beteg maga előtt, ellenállással szemben megemeli, a fájdalom az ín vájulata felett jelentkezik) pozitivitása irányadó. Ezen tünetek együttes fennállása 90\%-ban valószínúsíti a diagnózist.

A de Quervain-szindróma a kéz I. extensor rekeszében futó inak gyulladása miatt kialakuló, mozgatásra erősödő, csuklófájdalommal járó kórkép, a musculus abd. pollicis longus és musculus extensor pollicis brevis közös ínhüvelyének stenotizáló gyulladása. Kiváltó okok között szerepel a krónikus túlterhelés, főleg a számítógépbillentyüzet tartós használata, esetleg írás. Klinikai tünetek közül első helyen a foveola radialis körüli fájdalom, duzzanat és a mozgáskor érezhető crepitatio érdemel említést. Provokációs próbájánál a Finkelstein-jel pozitivitását vizsgáljuk, a hüvelyujj tenyér felé való behajlítása és a kézfej ulnar irányba való passzív feszítése fájdalmat provokál az ínhüvely mentén.

A pattanó ujj az ujj hajlítóinának elhúzódó gyulladása vagy az inat leszorító szalagos gyưrük hegesedése miatt alakul ki. Az ínon duzzanat, csomó keletkezik. Az ujj hajlítása, nyújtása során fájdalom mellett pattanás észlelhető, amit a csomó heges kötegen való átugrása okoz. Patomechanizmus szempontjából megemlíthető, hogy a megvastagodott flexor ín mozgása nehezített az ínhüvelyben, az erôs flexorok behúzzák az ínt az ínhüvelybe, a gyenge extensorok nem tudják kihúzni azt. Emiatt sok- 
szor csak passzívan, a másik kéz segítségével extendálható az ujj. Kiváltó okként a túleróltetés említhető meg, amely gyulladást provokál és a következmény a csomó kialakulása.

Az Achilles-tendinitis az ín fájdalmas duzzanatával jár. Provokáló tényezőnek tekinthetőek a mikrotraumák. Ruptura a már degenerált ín túlerőltetése esetén szokott létrejönni. Ennek fizikális vizsgálati jele, hogy a lábujjhegyre állás, illetve a lábfej aktív mozgatásakor a plantarflexió nem jön létre. Az Achilles-ín súrlódását a bursa subachillea mérsékli. A bursák, azaz a nyáktömlők két szövet egymáson való siklását, elmozdulását segítik elő, voltaképpen zárt zsákok. Belső felületüket az ízületi belhártyához hasonló synovialis membrán borítja. A nyáktömlők bélése az ízületi hártyához hasonló, így a bursitis voltaképpen lokális synovitis. A bursitisek kiváltó oka lehet túlterhelés. Így a bursitis subachillea klinikai tünete a fájdalom, a lokális nyomásérzékenység, felületes bursák gyulladása esetén duzzanat, bőrpír is észlelhető lehet. Egyéb gyakori bursitisek a bursitis subacromialis és bursitis subdeltoidea. Provokáló tényező: a vállízületi túlterhelés, míg a bursitis olecrani esetén a tartós könyöklés. A bursitis trochanterica esetén (a bursa a femur trochanter maiora felett található) a csípő kifelé rotációja és ráfekvés provokálja a fájdalmat.

A térd körüli bursitisek közül jellegzetes a bursitis praepatellaris, amelyet apácatérdnek is neveznek, de parkettázók körében is gyakori lehet. A provokáló tényező valószínúleg a kemény felületen való tartós térdelés. A bursitis infrapatellaris létrejöttében is térdelésnek tulajdonítható a föszerep. A bursitis suprapatellaris az egyik leggyakoribb, térd körüli bursitis. Kialakulásában trauma, meniscus-laesio, inflammált arthrosis, ízületi gyulladás játszik gyakran szerepet, de bármely térdízületi exudatív synovitis részeként jelentkezhet.

A bursitis anserini főleg labdarúgás, futás hatására alakul ki. Ez a bursa a pes anserinus Halleri alatt helyezkedik el. A Baker-cysta, más néven poplitealis cysta, a fossa popliteában helyezkedik el, általában térdízületi synovitis következményeként alakul ki. A járás során az ízületben termelődött folyadék az ízülettel közlekedő cystába préselődik. A Baker-cysta rupturálva mélyvénás thrombosis tüneteit utánozhatja.

A periarthritis humeroscapularis gyújtőfogalom: a vállízület körüli lágyrészek akut vagy krónikus, fibrotizáló gyulladása. Nyugalomban is fennálló fájdalommal jár, amely terhelés hatására fokozódhat, jellemző tünete eleinte a fájdalom provokálta, később a vállízületi tok, inak, szalagok inaktivitás okozta zsugorodása következtében létrejövő mozgásbeszúkülés.

A térdizületi meniscusok sérüléséhez vezető leggyakoribb kiváltó tényezők közé tartoznak a rotációs, azaz csavaró térdmozdulatokkal járó tevékenységek. Ennek során a medialis vagy a lateralis meniscus sérülhet. Kockázati tényezőnek tekinthetőek az alsó végtagi tengely- deformitások, valamint a térdízületi szalagok sérülései miatt kialakult instabilitás. Csavarodással járó mozdulatnál jelentkező reccsenésről, szúró jellegű fájdalomról, a térdízület duzzanatáról, illetve elakadási tünetról számol be a betegek többsége. A diagnózisra vezető tünet az elakadás. A fizikális vizsgálat során a McMurray-teszt és az Apley-féle teszt segít elkülöníteni a meniscus-, illetve a szalagsérüléseket, továbbá a meniscussérülésen belüli oldaliságot. A sérülés pontos lokalizálásához képalkotó vizsgálatok ajánlottak. Mivel az ízületi ultrahangvizsgálat szenzitivitása csak 65\%, többnyire MR-vizsgálat elvégzése szükséges.

A gerinc degenerativ elváltozásai által okozott fájdalmak többsége krónikus jellegü, amelyek a gerinc valamennyi alkotóeleméból származhatnak. A gerinc mechanikai és anatómiai múködési egysége a szegmentum, amelyet két szomszédos csigolya, a köztük lévő porckorong, az ízületek, a szalagok, mint passzív alkotóelemek, valamint a spinalis izomzat, mint aktív alkotóelem építenek fel. Az egymás feletti szegmentumok viszonylag kis mozgásterjedelmének összeadódása eredményezi az adott gerincszakasz, illetve végeredményben a teljes gerinc mozgásterjedelmét. A legérintettebb területek a nyaki és az ágyéki gerinc, mivel ezek vannak a legnagyobb igénybevételnek kitéve, és egyben a legmozgékonyabb szakaszok. A porckorongok degenerációja ezeken a szakaszokon kezdődik. A rugalmatlan porckorong a szegmentum instabilitásához vezet. A krónikus instabilitás és az aktuális megterhelés és/vagy túlmozgás ellentmondásából származnak a distorsiók okozta átmeneti fájdalmi szindrómák. Amennyiben ideggyöki kompreszszió is bevonódik az aktuális patológiába, neuropathiás fájdalmi komponens is csatlakozhat.

A gerinc eleve meglévő alaki vagy funkcionális rendellenességei kedveznek az egy vagy több szegmentumban bekövetkező porckorong-degenerálódásnak. Ilyen elváltozások: spondylolysis, spondylolisthesis, az ágyéki gerinc normálistól eltérő lordosisa, a Scheuermann-kór, az alsó végtagi hosszkülönbség, a scoliosis, átmeneti csigolya megléte, korábbi csigolyatörés, gyulladásos folyamat (spondylodiscitis), osteoporosis, egyéb csontanyagcsererendellenességek. A gerinc gyulladásos betegségei lényegében olyan enthesitisek, amelyek a gerinc szalagrendszerében zajlanak. Jellemzőjük a gyulladásos, azaz éjszaka fellépő és mozgásra enyhülő fájdalom.

\section{Az izmok túlzott, illetve egyoldalú igénybevétele által okozott betegségek}

A paravertebralis izomzat túlterhelése, főleg a nyaki paravertebralis és a trapezius izomzat feszessége, úgynevezett nyaki myalgia tartozik e fogalomkörbe. Etiológiaként az izmok statikus túlterhelése emelhető ki, csökken a feszes izmokban futó erek keringése, folyamatos izomkontrakció, végső soron ischaemiás fájdalom alakul ki. 


\section{Az izületek egyoldalú igénybevétele által okozott betegségek}

A sokízületi gyulladás által fenntartott nociceptív fájdalom mértéke az igénybevétellel arányos. A destruált, anatómiailag károsodott ízületeken megváltoznak az erőkarok és nyomatékok, amelyek eleve kedvezótlen ergonómiai helyzetet hoznak létre és fokozzák az igénybevételt. Az arthrosis a porc mennyiségi és minőségi károsodásával járó degeneratív ízületi megbetegedés. Leggyakrabban érintett ízületek közé a teherviselő alsó végtagi ízületek, csípő-, térd-, valamint a kéz- és az acromioclavicularis ízület tartozik. Befolyásoló rizikótényezők között emelhető ki fóleg férfiak arthrosisa esetén a meniscus és a keresztszalagok fennálló károsodása, ezzel 5-10-szeresére nő az előfordulási gyakoriság. Menisectomia önmagában is növeli az arthrosis gyakoriságát. Nőknél a testtömegnek (BMI) van jelentős szerepe. Kétegységnyi $(5 \mathrm{~kg})$ növekedés a testsúlyban az arthrosis gyakoriságát 40\%-kal növeli. Túlterhelés, mikrotraumák (például guggolás, térdelés) 2-4-szeresére emelik a térdarthrosis kialakulásának kockázatát. A csípőízületi arthrosis előfordulását az obesitas, túlzott fizikai igénybevétel, ízületi dysplasia, osteonecrosis, protrusio acetabuli, korábbi trauma, törés növeli.

\section{A regionális mozgásszervi szindrómák jelentkezésének kitett kockázati betegcsoportok}

\section{A foglalkozással összefüggö regionális mozgásszervi fájdalmi szindrómák}

Tágabb értelemben a munkakörülményekkel összefüggésbe hozható betegség minden olyan, a munkavégzés, a foglalkozás gyakorlása közben vagy azt követően megjelenő heveny vagy idült egészségkárosodás, amely az adott tevékenység során elóforduló fizikai, kémiai, biológiai, pszichoszociális és ergonómiai kóroki tényezőkre vezethetố vissza. Foglalkozási betegséget okozhat, ha a munkavállaló az optimálisnál nagyobb, esetleg kisebb igénybevételnek van kitéve. A foglalkozással, munkakörülményekkel összefüggésbe hozható betegségek leggyakoribb lokalizációja a mozgási szervrendszer [1521]. A mozgásszerveket érintố foglalkozási betegségek multifaktoriálisak [15]. Kialakulásukban elsőrendű́ek az egyéni, belsô rizikótényező́k, például a testalkat, a fizikai állapot, a gyakorlottság, a pszichoszociális tényezők, a stressztứró képesség és az egyéb társuló betegségek. A külső kockázati tényezók között dominál a munka jellege (fizikai erőkifejtés igénye, erőhatások és nyomaték, ismétlődő, monoton munkamozzanatok és terhelő egyéb munkakörülmények, látási viszonyok, a vibrációs ártalom és a zajszint) $[15,22-26]$.

$\mathrm{Az}$ anatómiai-funkcionális háttér tisztázásához azonban a munkakörülményekkel összefüggésbe hozható megbetegedések között pontosan el kell különíteni a foglalkozási betegséget. Utóbbi diagnosztizálásának döntő kritériuma a kizárólagos ok-okozati összefüggés a foglalkozás, a munkahelyi megterhelés és a betegség létrejötte között. Sok jelenség esetében ez az egyik legnehezebb feladat, egyedi elbírálást igényel. A mozgásszervi klinikai diagnózis tehát önmagában nem képezheti a foglalkozási megbetegedés diagnózisának alapját. A foglalkozási betegségek alapkérdése, hogy meg lehet-e határozni a foglalkozással összefüggő betegségekben a foglalkozási tényezők kóroki felelősségének arányát, illetve azt a szintet, hogy foglalkozási eredetúnek minősíthető az elváltozás.

A foglalkozással összefüggő mozgásszervi betegségek diagnosztikája megfelel a foglalkozással kapcsolatba nem hozható betegségek kórismézésére vonatkozó szakmai szabályokkal, protokollokkal. A diagnosztika alappillére annak elemzése, hogy a foglalkozási tényezők a betegség kialakulásában, illetve annak progressziójában milyen mértékben vehetők figyelembe. A mozgásszervek terhelésével járó munkakörökre való alkalmasság megítéléséhez a pályázó mozgásszervi státuszának, a veleszületett, illetve egyéb hajlamosító tényezőknek ismerete elengedhetetlen. Ha már kialakult mozgásszervi károsodás foglalkozással való összefüggését elemezzük, a munkakörülmények pontos ismerete a kóroki tényezők minősítéséhez elengedhetetlen.

\section{Amatör és versenysportolók mozgásszervi eredetü fájdalmi szindrómái}

Hazánkban 550 ezer igazolt amatőr és versenysportolóról tudunk, emellett $1-3$ milliót is kitehet azok száma, akik alkalomszerúen vagy kisebb-nagyobb rendszerességgel sportolnak. Túlnyomó részük viszonylag szerény edzettséggel, rendszertelenül végzi sporttevékenységét, az idősebb korosztály korlátozott mozgásszervi adottságokkal rendelkezik. A választott sporttevékenység során viszont óhatatlanul szükség van nagyobb erőkifejtéssel járó, gyors reagálást igénylő mozgásformákra. Ez az ellentmondás sérülékenyebbé teszi a sportolót. Az edzett, megfelelő fizikai állapotban lévő versenysportolót viszont sokszor a teljesítmény kényszere készteti nagy energiát igénylő és/vagy tartós mozgásformákra. Mindkettő a sportsérülés kockázatát rejti magában [27-29].

A sportsérüléseket feloszthatjuk akut sérülésekre, túlterheléses sérülésekre, krónikus sérülésekre és újrasérülésekre. Az akut sérülések hatásmechanizmusuk alapján hirtelen erőbehatásra jönnek létre egy adott erőbehatást követően. Az érintett szövet folytonossága megszakad, így csonttörés, izomszakadás, szalagszakadás, rándulás, ficam, zúzódás, sebek jöhetnek létre, amelyek az ízület mozgásának korlátozottságát, fájdalmát, duzzanatát eredményezhetik, haematomát, deformitást okozva.

A túlterheléses sérülések többnyire monoton és tartós erőbehatásra jönnek létre. Jellegzetes formájuk a stressztörés, aminek a lényege a csont meggyengülése és követ- 
kezményes törése. A katonák marsch fracturája szintén ismert és érthető jelenség. Okai között belső és külső tényezők egyaránt állhatnak. Ma a sportsérülések több mint felét is kitehetik, ami azért is jelentős, mert diagnosztikájuk és a törés ellátása csak tûzoltást jelent.

A krónikus sérülésekre jellemző, hogy egy elszenvedett sérülés után a tartós és eredménytelen kezelés krónikus, elhúzódó állapotot teremthet, amely akár hosszú éveken át okozhat mozgáskiesést, de egy túlterheléses sérülés nem megfelelő ellátása, illetve prevenciója is okozhat krónikus tüneteket. Komoly jelentőségét adja az a tény, hogy aszimmetrikus, kóros mozgásformák jelennek meg, amelyek már középtávon több szomszédos ízületen is komoly panaszokat eredményeznek.

Újrasérülésről akkor beszélünk, amikor a sportoló sportba visszatérése után egy hónapon belül újra megsérül. Ez egy komoly sportrehabilitációs probléma, mivel számos tényező vezethet ide, amelynek oka lehet külső és belső tényező egyaránt. A sérülések mellett azonban megjelenhetnek olyan mozgásszervi problémák is a sportolók körében, amik sérüléstől függetlenül is kialakulhatnak, azonban a sporttevékenység vagy a járulékos sérülések azokat súlyosbíthatják. Ilyenek például: a discushernia, spondylolysis, spondylolisthesis, radiculitis, fejlődési rendellenességek okozta funkciózavarok. A kutatási és nyomon követési adatok, közlemények többnyire a sporttevékenységgel kapcsolt olyan állapotokra adnak erősebb bizonyítékot, amelyeknek nagyobb a prevalenciája. Ezek közül kiemelt figyelmet kap a térdízületi elülső keresztszalag sérülése, akárcsak a bokadistorsio és bokaszalag-szakadások, epicondylitisek, Achilles-tendinitis, vállsérülések. A jellegzetes nagy energiájú és/vagy tartós igénybevétel speciális esete az ischiocruralis izomzat és eredésének sérülése, enthesitise (hamstring szindróma), amely súlyemelőknél, hosszútávfutóknál, extrém fitneszaktivitás során lép fel. Fő kockázata a terápiarezisztencia és a krónikussá válás.

A sportolók esetében a fizikai terhelésen túlmutatóan gyógyszeres kezelésüket illetően több speciális kérdés és súlypont is megjelenik. Így kiemelten figyelni kell arra a tényre, hogy a nagyobb fizikai megterhelés jelentős vízveszteséget produkál, komoly terhelést kap a renalis és cardiopulmonalis rendszer is. A gyógyszerek lebontása csökkenő kiválasztás esetén elhúzódhat, a vese mellett a máj is terhelődhet a lebomlás során. Idős sportolók, illetve a napjainkban egyre több szervtranszplantált sportoló esetén nagy figyelmet és mérlegelést igényel a tüneti gyógyszeres kezelés hatékony, de racionális és biztonságos vezetése.

Nem elhanyagolhatóak a doppingtilalomból származó korlátozások. A doppingszer olyan tiltott eszköz, amelynek segítségével a sportoló fokozza teljesítményét. A teljesítményjavítás már az ókorban megjelent, a görög atléták gombákat és növényi kivonatokat használtak a győzelem érdekében. A versenysport üzleti vonzatai miatt valóságos hajsza indult meg minden olyan eszköz használata érdekében, ami az egyéni teljesítményt fokoz- hatja, de nem felismerhető. A doppingszernek minősített készítmények hiányos ismerete nem mentesíti az akár jóhiszemú felhasználót és a kezelés elrendelőjét a következmények alól. Hazánkban a tiltott gyógyszerek és hatóanyagok listája egyszerűen és könnyen elérhető az antidopping.hu weboldalon. Számos OTC-készítmény vagy akár nyomelemeket tartalmazó szer is doppinglistás. A doppingellenes nemzetközi szervezet, a WADA weboldalán szintén pontos információ nyerhető a tiltott szerekról [30]. Adott esetben a nem szteroidok alkalmazását is be kell jelenteni a doppingellenőrző intézményeknek. A tiltott gyógyszerek ismerete minden orvos számára fontos, aki élsportolót kezel, mivel használatuk tiltott, illetve engedélyköteles.

\section{A nem szteroid gyulladáscsökkentők helye a mozgásszervi fájdalmak csillapításában}

A fájdalomcsillapítás terápiás irányelvei szerint az első feladat a fájdalom okának lehető leghamarabbi azonosítása. Feltárása a beteg közvetlen részvételét és együttmúködését igényli, ezért meg kell nyerni bizalmát. A feltárt okok által megszabott lehetőségekről a beteget objektíven tájékoztatni kell. A kezelési lehetőségek alkalmazásában a fokozatosságot kell szem előtt tartani. Ezért széles körben kell alkalmazni a nem gyógyszeres módszereket, és a lehető legkevésbé kockázatos és invazív eljárásokat kell választani.

Az akut fájdalmat azért kell agresszíven kezelni, hogy megakadályozzuk a szenzitizációt és a krónikussá válást, a krónikus fájdalmat viszont folyamatosan kezelni kell. A lehető legobjektívebb módon monitorozni kell a fájdalmat, és a kezelés agresszivitását a fájdalom fokához kell adaptálni. A fájdalom kezelése során törekedni kell a múködőképesség és az élet minőségének fenntartására $[31,32]$.

Valamennyi kezelési stratégia célja a fájdalom hatékony csillapítása. Ennek megfelelően a fájdalom intenzitásának és a perifériás fájdalom típusának (nociceptív, neuropathiás, kevert) megfelelő gyógyszert kell kiválasztani.

Enyhe fájdalomban (VAS 10-40) minor analgetikum, ezen belül gyulladásos komponens esetén NSAID adandó. Közepes erősségü fájdalomban (VAS 40-60) gyenge opioid ajánlott, amely a hatás fokozására kombinálható minor analgetikummal, gyulladásos komponens esetén nem szteroid gyulladáscsökkentővel is. Gyulladásos komponens hiányában az NSAID korlátozottan csillapítja a fájdalmat. A perifériás nocicepció és a gerincvelői integráció szintjén minor analgetikumként az acetaminophen/paracetamol, az NSAID-ok és a gyenge opioidok az első vonalban ajánlott készítmények [33]. A leggyakrabban használt gyenge opioidok a tramadol, a dihidrokodein, kodein. Alkalmazásuk során figyelemmel kell lenni az egyéni fogékonyságra, amit a citokróm P450 izoenzim CYP2D6 fenotípusa határoz meg. A gyenge opioidok addiktív hatása kisebb, mint a major opioidoké, 
de légzésdeprimáló és a tubularis vesefunkciókat károsító hatásuk kockázatokat hordoz az idősek krónikus fájdalmainak kezelése során, ezért adagjukat a beteg egyéni élettani jellemzőinek figyelembevételével kell beállítani. A tramadol kettős hatásmódja révén, szerotoninfelhalmozódás miatt, szerotoninszindrómát okozhat, különösen a szerotoninvisszavétel-gátló (SSRI) kezelésben részesülőkben [34]. A rendszerbetegségek okozta fájdalmakat az anticitokin-terápia mérsékli okszerúen.

Az izomrelaxánsok adjuváns terápiaként jönnek szóba. NMDA-gátlók (ketamin) és kannabinoidok hazánkban nincsenek használatban. Vertebrogen neuropathiás és kevert fájdalmakban az epiduralis analgesia jöhet szóba. A neuropathiás fájdalmakban, a központi idegrendszeri feldolgozás zavaraiban a pszichésen megélt fájdalom szintjén az erősebb opioidok, antidepresszánsok, antikonvulzív szerek, dopaminagonisták és pszichés technikák (kognitív viselkedési terápia) állnak a kezelés középpontjában [35]. Regionális és ismétlődő mechanikus eredetű fájdalmakban a lokális NSAID-terápiák korszerü transdermalis módját célszerü első vonalban alkalmazni [36-38].

Az American College of Rheumatology (ACR) a kéz-, csípő- és térdarthrosis gyógyszeres és nem gyógyszeres terápiájának 2012-ben közreadott irányelve tartalmazza, hogy mely régió arthrosisa esetén mely terápiák javallottak. Térdarthrosisban az acetaminophen és az oralis NSAID után a helyi NSAID-ok következnek választásra ajánlott gyógyszercsoportként. A kapszaicintartalmú lokális szerek a chondroitin-szulfát és a glükózamin adásával azonos indikációs szinten szerepelnek. A kézízületek arthrosisában az elsőként ajánlott gyógyszeres terápiás lehetőségek között szerepelnek a helyi kapszaicin, a helyi NSAID-ok, ideértve a szaliciláttartalmú készítményeket is. Csak ezt követő választásként javasolják az oralis NSAID-okat, köztük a szelektív COX-2-inhibitorokat, valamint a tramadol alkalmazását. Kiemeli az ajánlás, hogy 75 év feletti korcsoportban a helyi készítményeket ajánlott előnyben részesíteni az oralis készítményekkel szemben [39].

$\mathrm{Az}$ Osteoarthritis Research Society International (OARSI) a térdarthrosis nem sebészi kezelésére 2014ben kiadott irányelve kiemeli a különböző terápiákat illető eredmény-kockázat elemzésekben, hogy az oralis NSAID-adás kockázata már a kevésbé súlyos társbetegségek fennállása esetén is jelentős a várható eredményhez képest, míg a lokális NSAID-ok esetén a várható eredmény minden betegcsoportban meghaladja a várható kockázatot.

Az ajánlásokhoz kiemelik továbbá, hogy a tapaszok és a peroralis készítmények kombinálhatóak is, így a peroralis adagok csökkenthetők. Ezáltal lehetőség nyílik a dózisfüggő mellékhatások kivédésére.

A mozgásszervi fájdalmak túlnyomó része azonban nem a krónikus degeneratív és gyulladásos kórképek folyamataiból, hanem a lágyrészek epizódszerú akut és szubakut fájdalmi szindrómáiból származik. Az akut túl- használati, túlterheléses lágyrész-sérülések - köztük a sporttevékenység és foglalkozáshoz kötött aktivitás kapcsán létrejövőkkel - ellátásának alapköve a RICE-protokoll (rest, ice, compression, elevation), ami nyugalomba helyezést, napi minimum hat-nyolc alkalommal 20-20 perces jegelést, rugalmas pólyával történő rögzítést és felpolcolást jelent.

A szubakut és krónikus szakaszban fóleg a tapaszok és gélek alkalmazása terjedt el a napi gyakorlatban. A metilszalicilát, mentol, kámfor és kapszaicin hatásos hatóanyagok a különböző tapaszokban és kenőcsökben. Lokális NSAID - fóleg ketoprofen és diclofenac - használata rándulás, húzódás és zúzódás esetén, valamint akut és krónikus sporteredetű lágyrész-sérülések esetén hatékonynak bizonyult. A sérülés utáni első három-hét napban történő alkalmazásukkal lerövidíthető a sérült inaktivitása, gyorsabb visszatérés várható [40-45].

A nagyízületi szalagsérülések és izomsérülések utáni első napokban adva, a lokális és peroralis NSAID-ok kiemelkedően csökkentik a duzzanatot és a fájdalmat. Váll körüli bursitisek és de Quervain-tendinitis esetén COX1- és COX-2-gátlók, naproxen és celecoxib egyaránt hatékonyan csökkentik a gyulladást és segítik a felépülést [46-52]. Túlterheléses sérülések esetén azonban csak fájdalomcsillapító hatásuk van, így a gyógyulás folyamatát nem befolyásolják. A nem szteroid gyulladáscsökkentők használata előnyös az izom mélyre ható zúzódása esetén is. A szöveti ödémát csökkentve lehetővé teszik a regenerációt, így közremúködnek az izommúködés helyreállításában. Ezáltal és a fájdalom csillapítása révén visszaállítják a károsodott mozgásfunkciót [52-57].

\section{A nem szteroid gyulladáscsökkentő készítmények hatásosságának meghatározó tényezői}

A széles körben, változatos kiszerelésben alkalmazott eredeti és generikus készítmények hatásosságának jelentős tényezője a készítményben lévő hatóanyag homogén vagy heterogén szerkezeti szimmetriája (kiralitása). A szerves vegyületek a szénatomok kétféle térbeli elhelyezkedése következtében egymást tükörképszerüen fedő, kétféle változatban létezhetnek (sztereoizomerek). Hagyományosan a kétféle változatot aszerint különböztetik meg, hogy a polarizált fény síkját jobbra vagy balra forgatják el. Az egy szénatom két változatát tartalmazó izomerek fizikai és kémiai tulajdonságai, így biológiai hatásaik is egyezőek. A legalább két aszimmetrikus szénatomot tartalmazó vegyületek tulajdonságai és biológiai hatásai eltérhetnek. A szervezet saját molekulái egyféle kiralitásúak (az aminosavak mind balra forgatók), a szintetikus vegyületek a térbeli változatok keverékét (racem) tartalmazzák. A gyógyszergyártás során a készítménybe célszerüen a hatóanyagnak csak a biológiailag aktív változata kerül. A leválasztás költségeit a kisebb anyagigény ellensúlyozza. Ezenkívül a homogén készítmények biz- 
tonságosabbak is. Minthogy az ibuprofen tiszta jobbra forgató izomerjének tolerálhatósága különösen kedvező, a dexibuprofentolerancia az NSAID-szerek közötti öszszehasonlítás alapja.

A mozgásszervi betegségek tüneteinek kezelésére leggyakrabban a hazánkban törzskönyvezett nem szteroid gyulladáscsökkentőket alkalmazzuk (1. táblázat). A 2. táblázat az elöírt és általánosan alkalmazott felnőttadagokat és a gyermekkorúak számára törzskönyvezett készítmények adagjait mutatja be. Ezek fájdalomcsillapító (analgetikus), hőcsökkentő (antipiretikus) és magasabb dózisban gyulladáscsökkentő hatással rendelkeznek. $\mathrm{Az}$ acetilszalicilsavnak cardiovascularis tekintetben fontos thrombocytaaggregáció-gátló aktivitása is van. Az NSAID-ok kémiailag igen változatos gyógyszercsoportot képeznek, de mindegyikük rendelkezik ciklooxigenáz-gátló (COX) képességgel, és az ebből adódó prosztaglandinbioszintézis-gátlás nagymértékben felelős terápiás hatásukért.

Az NSAID-ok számos mechanizmussal gátolják a COX-ot. A ciklooxigenáz enzimnek, jelen ismerteink alapján, kétféle, az emberi szervezetben aktív izoformja létezik, a COX-1 és a COX-2. Az egyes COX-bénítók hatásspektruma abból adódik össze, hogy az enzim melyik izoformját, milyen szövetben expresszált, konstitutív vagy indukálható válfaját, peroxidáz és/vagy oxigenáz komponensét milyen preferenciával és irreverzibilitással bénítják. Így a metamizol hatástanilag nem szteroid gyulladáscsökkentőnek tekinthető, minthogy hatásos fájdalomcsillapító és lázcsillapító, a központi idegrendszeri COX-1b enzimet (az egyes állatokban aktív COX-3) gátló hatása révén azonban, az ugyanígy ható paracetamolhoz hasonlóan, gyulladáscsökkentő hatása nincs. A másik példa a fenilbutazon, mint a legrégebbi hatásos perifériás COX-1b-gátló, amely erős COX-1-szelektivitása miatt gyomor-bél rendszeri kockázatokat hordoz, mint például a butazolidin, amely myelotoxicus és májkárosító, ezért csak korlátozottan alkalmazható, helyi (kenőcs kiszerelésben), illetve rövid időtartamú per os kezelésként.

A COX-1 enzim valamennyi humán sejttípusban konstitutívan expresszálódik, és számos fiziológiás folyamat, így például a gyomormucosa védelmének szabályozásában fontos szerepet játszik. Ezzel szemben a COX-2 enzim bizonyos stimulusok hatására számos gyulladásos sejtben expresszálódik és bár a COX-1 enzimmel megegyező produktumok termelődését szabályozza, de azt csak a gyulladás helyén végzi. Ebből adódóan ezen enzim gátlása felelős az NSAID-készítmények gyulladásgátló hatásaiért. Az NSAID-készítmények hatásainak és mellékhatásainak kialakulásáért egyaránt a COX enzimeken keresztül megvalósuló prosztaglandinszintézis gátlása a felelös. A COX-2/COX-1 hányados minden NSAID-ra külön-külön jellemző érték, amely meghatározza, hogy az adott szer ugyanazon mennyisége mekkora mértékben gátolja a COX-1, illetve COX-2 enzimet. Ezek alapján az 1 körüli COX-2/COX-1 hányadossal rendelkezők (például diclofenac) adott mennyisége nagyjából azonos mértékben gátolja mindkét izoenzimet. Warner és mtsai a „teljes vér” módszerrel egy ido”ben tesztelték az ismert NSAID-okat, a COX-2/COX-1 arány alapján egy kontinuus skálát hoztak létre [58]. Mindezek alapján a rofecoxib, celecoxib, nimesulide, meloxicam ezen in vitro teszt alapján szelektív COX2-gátlóknak, a flurbiprofen, aszpirin, ketoprofen, naproxen, indometacin stb. pedig szelektív COX-1-gátlóknak tekinthetők. Számos tanulmány igazolta a coxibok, a nimesulid és meloxicam kedvezőbb GI-profilját. Az NSAID-ok analgetikus hatásukat mind perifériásan, mind centrálisan kifejtik, de a perifériás hatás a meghatározó. Analgetikus hatásuk rendszerint összefügg gyulladáscsökkentő hatásukkal, és ez a gyulladt szövetben a prosztaglandinszintézis gátlásából ered. Maguk a prosztaglandinok csekély mértékú fájdalmat okoznak, de potencírozzák az egyéb gyulladásmediátorok (például hisztamin, bradikinin) okozta fájdalmat.

A prosztaglandinok gyulladásban betöltött szerepe a vasodilatator hatás és a vascularis permeabilitás fokozása. Az NSAID-okkal történő prosztaglandinbioszintézisgátlás azonban inkább enyhíti, mint megszünteti a gyulladást, mivel a vegyületek nem gátolják a gyulladás többi mediátorát. Mindazonáltal az NSAID-ok viszonylag mérsékelt gyulladáscsökkentő hatása a legtöbb gyulladásos kórképben szenvedő beteg fájdalmát, ízületeinek és gerincének merevségét és a poszttraumás vagy gyulladásos duzzanatot is enyhítik, de nem változtatják meg a betegség lefolyását. Az NSAID-ok nem csökkentik a normális testhőmérsékletet. A láz során endogén pirogének (interleukin-1) szabadulnak fel a leukocytákból és közvetlenül a hypothalamusban lévő termoreguláló központra hatva emelik a testhőmérsékletet. A hatás az agy pirogén hatású prosztaglandinszintjének emelkedésével hozható összefüggésbe. Az acetilszalicilsav kivédi az interleukin-1 hőmérséklet-emelő hatását és az agyi prosztaglandinszint-emelkedést. A ciklooxigenáz enzim gátlása révén valamennyi NSAID-készítmény csökkenti a thrombocytaaggregációt, illetve gátolja a láz és a gyulladásos eredetű fájdalom kialakulását $[11,12,59]$.

\section{Az oralis, parenteralis és transdermalis gyógyszerbevitel sajátosságai}

\section{Per os gyógyszerbevitel}

A gyógyszerek nagyobbik része szájon át kerül adagolásra. Ahhoz, hogy a gyógyszerek kifejthessék a szervezeten belül a kívánt hatást, el kell jutniuk a célszervhez. Az alkalmazás helyéról a vérbe jutás folyamatát nevezzük felszívódásnak, a vérből a hatás helyére, azaz a szövetekbe jutást pedig eloszlásnak. A felszívódási útvonal peroralis gyógyszereknél a szájüreg, a nyelőcső, a gyomor, a vékonybél, a vena portae, a máj, végül a vena cava inferioron keresztül a szer bejut a szisztémás keringésbe. 
1. táblázat |A leggyakrabban használt nem szteroid készítmények *

\begin{tabular}{|c|c|c|c|c|c|}
\hline ATC-kód & Hatóanyag & Márkanév & Gyógyszerforma & $\begin{array}{l}\text { Hatóanyag- } \\
\text { mennyiség }\end{array}$ & Kiszerelés \\
\hline M01AB05 & Diclofenac & Cataflam C & Tabletta & $50 \mathrm{mg}$ & $20 x$ \\
\hline M01AB05 & Diclofenac & Cataflam V & Tabletta & $50 \mathrm{mg}$ & $20 x$ \\
\hline M01AB05 & Diclofenac & Cataflam & Csepp & $1,5 \%$ & $1 \times 15 \mathrm{ml}$ \\
\hline M01AB05 & Diclofenac & Flector Rapid & Granulátum & $50 \mathrm{mg}$ & $20 \times$ \\
\hline M01AB05 & Diclofenac & Flector Rapid & Granulátum & $50 \mathrm{mg}$ & $10 x$ \\
\hline M01AB05 & Diclofenac & Voltaren $\mathrm{Sr}$ & Filmtabletta & $75 \mathrm{mg}$ & $20 \times$ \\
\hline M01AB05 & Diclofenac & Voltaren & Injekció & $75 \mathrm{mg}$ & $5 \times 3 \mathrm{ml}$ \\
\hline M01AB05 & Diclofenac & Voltaren & Kúp & $50 \mathrm{mg}$ & $10 \times$ \\
\hline M01AB05 & Diclofenac & Voltaren Enter & Tabletta & $50 \mathrm{mg}$ & $30 x$ \\
\hline M01AB05 & Diclofenac & Voltaren & Tabletta & $100 \mathrm{mg}$ & $10 \times$ \\
\hline M01AB05 & Diclofenac & Voltaren Enter & Tabletta & $25 \mathrm{mg}$ & $30 x$ \\
\hline M01AB05 & Diclofenac & Voltaren & Filmtabletta & $100 \mathrm{mg}$ & $30 x$ \\
\hline M01AB05 & Diclofenac & Diclac & Tabletta & $75 \mathrm{mg}$ & $50 \times$ \\
\hline M01AB05 & Diclofenac & Diclac & Tabletta & $150 \mathrm{mg}$ & $20 x$ \\
\hline M01AB05 & Diclofenac & Fortedol & Filmtabletta & $50 \mathrm{mg}$ & $20 x$ \\
\hline M01AB05 & Diclofenac & Diclofenac Duo & Kapszula & $75 \mathrm{mg}$ & $30 x$ \\
\hline M01AB05 & Diclofenac & Diflam & Filmtabletta & $50 \mathrm{mg}$ & $20 x$ \\
\hline M01AB05 & Diclofenac & Diclofenac-Biogal & Filmtabletta & $100 \mathrm{mg}$ & $50 x$ \\
\hline M01AB05 & Diclofenac & Diclofenac-Biogal & Filmtabletta & $100 \mathrm{mg}$ & $20 x$ \\
\hline M01AB05 & Diclofenac & Diclofenac-Biogal & Filmtabletta & $100 \mathrm{mg}$ & $100 x$ \\
\hline M01AB05 & Diclofenac & Diclofenac-Ratioph & Filmtabletta & $50 \mathrm{mg}$ & $50 \times$ \\
\hline M01AB05 & Diclofenac & Diclofenac-Ratioph & Kapszula & $100 \mathrm{mg}$ & $20 x$ \\
\hline M01AB05 & Diclofenac & Diclofenac-Ratioph & Filmtabletta & $50 \mathrm{mg}$ & $30 x$ \\
\hline M01AB05 & Diclofenac & Diclofenac-Ratioph & Filmtabletta & $50 \mathrm{mg}$ & $100 x$ \\
\hline M01AE02 & Naproxen & Apranax & Filmtabletta & $550 \mathrm{mg}$ & $30 \times$ \\
\hline M01AE02 & Naproxen & Apranax & Filmtabletta & $275 \mathrm{mg}$ & $30 x$ \\
\hline M01AE02 & Naproxen & Analgesin & Filmtabletta & $550 \mathrm{mg}$ & $30 x$ \\
\hline M01AE02 & Naproxen & Analgesin & Filmtabletta & $275 \mathrm{mg}$ & $30 x$ \\
\hline M01AE02 & Naproxen & Naprosyn & Tabletta & $250 \mathrm{mg}$ & $30 x$ \\
\hline M01AB16 & Aceclofenac & Aflamin & Tabletta & $100 \mathrm{mg}$ & $30 \times$ \\
\hline M01AB16 & Aceclofenac & Aflamin & Tabletta & $100 \mathrm{mg}$ & $60 x$ \\
\hline M01AB16 & Aceclofenac & Aflamin Rapid & Por & $100 \mathrm{mg}$ & $20 x$ \\
\hline M01AB16 & Aceclofenac & Flemac & Filmtabletta & $100 \mathrm{mg}$ & $30 \times$ \\
\hline M01AB16 & Aceclofenac & Flemac & Filmtabletta & $100 \mathrm{mg}$ & $60 \times$ \\
\hline M01AE01 & Ibuprofen & Dolgit & Filmtabletta & $800 \mathrm{mg}$ & $20 x$ \\
\hline M01AE01 & Ibuprofen & Dolgit Akut & Kapszula & $400 \mathrm{mg}$ & $20 x$ \\
\hline M01AE01 & Ibuprofen & Dolgit Akut & Kapszula & $400 \mathrm{mg}$ & $10 x$ \\
\hline M01AE01 & Ibuprofen & Algoflex & Kapszula & $300 \mathrm{mg}$ & $20 x$ \\
\hline M01AE01 & Ibuprofen & Algoflex & Kapszula & $300 \mathrm{mg}$ & $30 x$ \\
\hline M01AE01 & Ibuprofen & Algoflex & Kapszula & $300 \mathrm{mg}$ & $10 x$ \\
\hline M01AE01 & Ibuprofen & Ibumax & Filmtabletta & $600 \mathrm{mg}$ & $30 x$ \\
\hline M01AE01 & Ibuprofen & Ibumax & Filmtabletta & $800 \mathrm{mg}$ & $30 \times$ \\
\hline M01AE01 & Ibuprofen & Ibumax & Filmtabletta & $600 \mathrm{mg}$ & $100 \times$ \\
\hline M01AE01 & Ibuprofen & Ibumax & Filmtabletta & $200 \mathrm{mg}$ & $100 x$ \\
\hline M01AE01 & Ibuprofen & Ibumax & Filmtabletta & $800 \mathrm{mg}$ & $10 x$ \\
\hline M01AE01 & Ibuprofen & Ibumax & Filmtabletta & $400 \mathrm{mg}$ & $30 x$ \\
\hline M01AE01 & Ibuprofen & Ibumax & Filmtabletta & $600 \mathrm{mg}$ & $10 x$ \\
\hline M01AE01 & Ibuprofen & Brufen Ret & Filmtabletta & $800 \mathrm{mg}$ & $30 x$ \\
\hline M01AE01 & Ibuprofen & Brufen & Pezsgőgranulátum & $600 \mathrm{mg}$ & $20 x$ \\
\hline M01AE01 & Ibuprofen & Brufen & Pezsgőgranulátum & $400 \mathrm{mg}$ & $20 x$ \\
\hline
\end{tabular}




\section{1. táblázat folytatása}

\begin{tabular}{|c|c|c|c|c|c|}
\hline ATC-kód & Hatóanyag & Márkanév & Gyógyszerforma & $\begin{array}{l}\text { Hatóanyag- } \\
\text { mennyiség }\end{array}$ & Kiszerelés \\
\hline M01AE01 & Ibuprofen & Spedifen & Granulátum & $600 \mathrm{mg}$ & $12 x$ \\
\hline M01AE01 & Ibuprofen & Spedifen & Granulátum & $400 \mathrm{mg}$ & $12 x$ \\
\hline M01AX17 & Nimesulide & Xilox & Granulátum & $100 \mathrm{mg}$ & $30 \times$ \\
\hline M01AX17 & Nimesulide & Mesulid & Tabletta & $100 \mathrm{mg}$ & $30 \times$ \\
\hline M01AX17 & Nimesulide & Mesulid & Granulátum & $100 \mathrm{mg}$ & $30 \times$ \\
\hline M01AX17 & Nimesulide & Nidol & Tabletta & $100 \mathrm{mg}$ & $30 \times$ \\
\hline M01AC06 & Meloxicam & Movalis & Tabletta & $15 \mathrm{mg}$ & $20 x$ \\
\hline M01AC06 & Meloxicam & Movalis & Injekció & $15 \mathrm{mg}$ & $3 \times$ \\
\hline M01AC06 & Meloxicam & Movalis & Tabletta & $15 \mathrm{mg}$ & $10 \times$ \\
\hline M01AC06 & Meloxicam & Meloxep & Tabletta & $15 \mathrm{mg}$ & $30 \times$ \\
\hline M01AC06 & Meloxicam & Meloxep & Tabletta & $15 \mathrm{mg}$ & $20 \times$ \\
\hline M01AC06 & Meloxicam & Meloxan & Tabletta & $15 \mathrm{mg}$ & $30 \times$ \\
\hline M01AC06 & Meloxicam & Meloxicam-Zentiva & Injekció & $15 \mathrm{mg}$ & $5 \times$ \\
\hline M01AC06 & Meloxicam & Meloxicam-Zentiva & Tabletta & $15 \mathrm{mg}$ & $20 \times$ \\
\hline M01AC06 & Meloxicam & Meloxicam Sandoz & Tabletta & $15 \mathrm{mg}$ & $30 \times$ \\
\hline M01AC06 & Meloxicam & Meloxicam Sandoz & Tabletta & $15 \mathrm{mg}$ & $20 \times$ \\
\hline M01AC06 & Meloxicam & Melodyn & Tabletta & $15 \mathrm{mg}$ & $30 \times$ \\
\hline M01ABII & Acemetacin & Rantudil Forte & Kapszula & $60 \mathrm{mg}$ & $20 \times$ \\
\hline M01AB11 & Acemetacin & Rantudil Retard & Kapszula & $90 \mathrm{mg}$ & $20 \times$ \\
\hline M01AX02 & Niflumic acid & Donalgin & Kapszula & $250 \mathrm{mg}$ & $30 \times$ \\
\hline M01AC01 & Piroxicam & Brexin & Tabletta & $20 \mathrm{mg}$ & $30 \times$ \\
\hline M01AC01 & Piroxicam & Brexin & Tabletta & $20 \mathrm{mg}$ & $20 \times$ \\
\hline M01AC01 & Piroxicam & Brexin & Por & $20 \mathrm{mg}$ & $20 \times$ \\
\hline M01AC01 & Piroxicam & Hotemin & Injekció & $20 \mathrm{mg}$ & $5 \times$ \\
\hline M01AC01 & Piroxicam & Hotemin & Kapszula & $20 \mathrm{mg}$ & $20 \times$ \\
\hline M01AC01 & Piroxicam & Hotemin & Kapszula & $10 \mathrm{mg}$ & $20 \times$ \\
\hline M01AC01 & Piroxicam & Hotemin & Kúp & $10 \mathrm{mg}$ & $10 \times$ \\
\hline M01AC01 & Piroxicam & Hotemin & Kúp & $20 \mathrm{mg}$ & $10 \times$ \\
\hline M01AC01 & Piroxicam & Feldene & Kapszula & $10 \mathrm{mg}$ & $30 x$ \\
\hline M01AC01 & Piroxicam & Feldene & Tabletta & $20 \mathrm{mg}$ & $30 \times$ \\
\hline M01AH05 & Etoricoxib & Arcoxia & Filmtabletta & $90 \mathrm{mg}$ & $28 \times$ \\
\hline M01AH05 & Etoricoxib & Arcoxia & Filmtabletta & $60 \mathrm{mg}$ & $28 \times$ \\
\hline M01AH05 & Etoricoxib & Arcoxia & Filmtabletta & $60 \mathrm{mg}$ & $14 \times$ \\
\hline M01AH05 & Etoricoxib & Arcoxia & Filmtabletta & $90 \mathrm{mg}$ & $14 \times$ \\
\hline M01AH05 & Etoricoxib & Arcoxia & Filmtabletta & $30 \mathrm{mg}$ & $14 \times$ \\
\hline M01AH05 & Etoricoxib & Arcoxia & Filmtabletta & $60 \mathrm{mg}$ & $7 \times$ \\
\hline M01AH05 & Etoricoxib & Arcoxia & Filmtabletta & $90 \mathrm{mg}$ & $7 \times$ \\
\hline M01AE14 & Dexibuprofen & Seractil & Filmtabletta & $400 \mathrm{mg}$ & $30 \times$ \\
\hline M01AE14 & Dexibuprofen & Seractil & Filmtabletta & $400 \mathrm{mg}$ & $20 \times$ \\
\hline M01AE14 & Dexibuprofen & Seractil Dolo & Filmtabletta & $300 \mathrm{mg}$ & $10 \times$ \\
\hline M01AEl4 & Dexibuprofen & Seractil Dolo & Filmtabletta & $300 \mathrm{mg}$ & $20 x$ \\
\hline M01AEl4 & Dexibuprofen & Seractil Dolo & Filmtabletta & $300 \mathrm{mg}$ & $30 \times$ \\
\hline M01AC05 & Lornoxicam & Xefo & Tabletta & $8 \mathrm{mg}$ & $30 \times$ \\
\hline M01AC05 & Lornoxicam & Xefo Rapid & Tabletta & $8 \mathrm{mg}$ & $20 \times$ \\
\hline M01AC05 & Lornoxicam & Xefo & Injekció & $4 \mathrm{mg}$ & $1 \times$ \\
\hline M01AB01 & Imdometacin & Indometacinum & Kúp & $100 \mathrm{mg}$ & $5 \times$ \\
\hline M01AB01 & Imdometacin & Indometacinum & Kapszula & $25 \mathrm{mg}$ & $30 \times$ \\
\hline M01AB01 & Imdometacin & Indometacinum & Kúp & $50 \mathrm{mg}$ & $10 \times$ \\
\hline M0lAH0l & Celecoxib & Celebrex & Kapszula & $200 \mathrm{mg}$ & $20 \times$ \\
\hline M01AH01 & Celecoxib & Celebrex & Kapszula & $100 \mathrm{mg}$ & $10 \times$ \\
\hline M01AH0l & Celecoxib & Celebrex & Kapszula & $200 \mathrm{mg}$ & $10 \times$ \\
\hline
\end{tabular}

*A tapaszok - a kombinált készítmények, gélek és krémek kivételével - külön táblázatban vannak feltüntetve. 
2. táblázat | A leggyakrabban használt nem szteroid gyulladáscsökkentők felnőttadagjai (a gyermekadagok „GY”jelöléssel szerepelnek)

\begin{tabular}{|c|c|}
\hline Aspirin & PO 325-650 mg 4-6 óránként, naponta legfeljebb 4 g. GY: maximális napi adag 10-15 mg/kg 2 részletben. \\
\hline Ibuprofen & $\begin{array}{l}\text { PO 400-800 mg szükség szerint, } 6 \text { óránként, maximális napi adag 3,2 g. GY: maximális napi adag } 15-40 \mathrm{mg} / \mathrm{kg} \\
\text { 3-4 részletben. }\end{array}$ \\
\hline Naproxen & $\begin{array}{l}\text { PO } 500 \mathrm{mg} \text { kezdó adag, majd } 250 \mathrm{mg} \text { 6-8 óránként, maximális napi adag 1,25 g. GY: maximális napi adag } \\
10-15 \mathrm{mg} / \mathrm{kg} 2 \text { részletben. }\end{array}$ \\
\hline Ketoprofen & PO 50 mg naponta $4 \times$ vagy 75 mg 3×, maximális napi adag $300 \mathrm{mg}$. \\
\hline Flurbiprofen & PO 200-300 mg naponta 3 vagy 4 részletben, maximális napi adag 300 mg. \\
\hline Indomethacin & PO 25-50 mg naponta $2 \times$ vagy $3 \times$, a maximális napi adag $200 \mathrm{mg}$. GY: maximális napi adag $1-4 \mathrm{mg} / \mathrm{kg} 2-4 \mathrm{részletben}$. \\
\hline Diclofenac & PO 150-200 mg naponta 3 vagy 4 részletben. GY: maximális napi adag 1-3 mg/kg 2-3 részletben. \\
\hline Nabumeton & PO 1000 mg naponta, a maximális napi adag 2000 mg. \\
\hline Piroxicam & $\begin{array}{l}\text { PO 10-20 mg naponta a maximális napi adag } 20 \text { mg. GY: maximális napi adag } 0,2-0,3 \text { mg napi egy adagban, csak } \\
\text { idősebb gyermekkorban. }\end{array}$ \\
\hline Meloxicam & PO 7,5-15 mg naponta egyszer, a maximális napi adag 15 mg. \\
\hline Mefenamic acid & PO 500-250 mg szükség szerint vagy 4 óránként, legfeljebb egy hétig. \\
\hline Celecoxib & PO 200 mg naponta. \\
\hline Etorixocib & PO 30-90 mg naponta. \\
\hline
\end{tabular}

A felszívódás zömmel a nagy felületû́ vékonybélből történik, s annál jobb, minél lipidoldékonyabb a vegyület.

A biológiai hasznosíthatóság (bioavailability) az a fogalom, amelyet a beadott gyógyszer szisztémás keringésbe jutó részének jellemzésére használunk. Intravénás injekciót követően a biológiai hasznosíthatóság 100\% $(\mathrm{F}=1)$, de a gyógyszereket általában oralisan adják, így a szisztémás keringést elérô mennyiség gyógyszerenként és betegenként is változik.

A gyomor-bél traktusból felszívódott gyógyszerek a portalis keringésbe jutnak, és egyesek a májon áthaladva jelentősen metabolizálódnak (first-pass metabolizmus). Azok a gyógyszerek, amelyek kellően lipidoldékonyak, gyorsan megoszlanak a szervezet víztereiben. Számos gyógyszer gyenge kölcsönhatással a plazmaalbuminokhoz kötődik, és így a plazmában a kötött és a szabad gyógyszermolekulák között egyensúly alakul ki. A plazmaproteinekhez kötött gyógyszer a keringésben marad és ezért nem képes farmakológiai hatását kifejteni. Az intravénás injekcióban adott gyógyszer azonnal a vérbe kerül és gyorsan megoszlik a szövetekben. Ismételt vérmintavétellel a gyógyszer plazmakoncentráció-csökkenését, azaz a gyógyszer eliminációs sebességét mérhetjük az idő függvényében.

Sok esetben a koncentráció először gyorsan csökken, majd ennek sebessége fokozatosan mérséklődik. Az ilyen görbét exponenciális függvénynek nevezzük, amely azt jelenti, hogy bármely időpillanatban a jelen lévő gyógyszer konstans hányada eliminálódik adott időegység alatt. Számos gyógyszer plazmakoncentrációja exponenciális csökkenést mutat, mivel az eliminációs folyamatok sebessége rendszerint maga is arányos a gyógyszer plazmakoncentrációjával. Ilyen folyamatok a glomerulusfiltráción keresztüli elimináció a vizeletben, a metabolizmus, rendszerint a májban, felvétel a májba és ezt követó elimináció az epével. Elsőrendúnek nevezzük azt a folyamatot, amely bármely idôpillanatban a gyógyszer koncentrációjától függ, és a legtöbb gyógyszer elsőrendû eliminációs kinetikát mutat. Ha a gyógyszer metabolizmusáért felelős bármelyik enzimrendszer telítődik, akkor az eliminációs kinetika nulladrendûvé válik, azaz az elimináció állandó sebesség mellett megy végbe és a gyógyszer növekvő koncentrációja azt nem befolyásolja. A gyógyszer-metabolizmust több tényező befolyásolhatja. Ilyen az enzimindukció és enzimgátlás (citokróm P-450), a genetikai polimorfizmus (a gyenge hidroxilálók, gyors és lassú acetilálók), a glomeruláris filtráció, amely a renalis keringés, közvetve az életkor függvénye.

$\mathrm{Az}$ oralisan alkalmazott gyógyszerek a szisztémás keringésbe kerülésük előtt metabolizálódnak felszívódás során az epithelsejtekben, illetve a májban. Ez utóbbit nevezzük first-pass hatásnak, amelynek következménye a vér gyógyszer-koncentrációjának csökkenése. Nagyobb gyógyszerdózisok esetében a first-pass metabolizmus telődik, a gyógyszer biológiai felhasználhatósága megnövekedhet. A first-pass hatás kikerülhető, amikor parenteralisan, rectalisan, buccalisan, transdermalisan vagy inhalációs módon adjuk a gyógyszert [60].

\section{A parenteralis gyógyszerbevitel sajátosságai}

A parenteralis adagolás gyakori formája az intravénás beadási mód, amikor nem beszélhetünk felszívódásról, hiszen felszívódás alatt a gyógyszernek az alkalmazás helyéről a vérbe jutását értjük. Ekkor pedig a gyógyszert egyenesen a vérbe juttatjuk. Az intravénás beadás azonnali hatást eredményez. Olyankor alkalmazzuk, ha gyors hatást kívánunk elérni vagy a gyógyszer bizonytalanul szívódik fel, esetleg erősen szövetizgató, vagy akár gyorsan metabolizálódik per os adagolás után. Az intravénás 
adagolás fó veszélye a túladagolás, hiszen ilyenkor nincsen mód a gyógyszer egyszerú eltávolítására a szervezetből.

A másik parenteralis adagolási mód az intramuscularis. A felszívódást jelentősen befolyásolja a vérellátás, a kötőszövet denzitása. Érszúkítő vagy értágító gyógyszerek együttes adása jelentősen befolyásolja a folyamat sebességét. Főleg a helyi érzéstelenítőket adják együtt érszúkítókkel, felszívódásuk lassítására. Az adagolt gyógyszer fizikokémiai tulajdonságai jelentősen befolyásolják a felszívódást. Fontos a lipid-víz megoszlási hányados, a viszkozitás, a pH, a koncentráció, a volumen, az oldószer stb. Ismeretesek olyan subcutan és intramuscularis készítmények, amelyek depót képeznek a beadás helyén, és napokig vagy hetekig terápiás vérszintet biztosítanak. Ilyenek lehetnek a vizes gyógyszerszuszpenziók (például szteroidok), de olajos oldatok (például etofenamát) is. Ennek az adagolási formának a gyors és biztonságos felszívódás az előnye, de hátrányai is vannak. Az injekció fájdalmas lehet, lokális szöveti izgalmat válthat ki (fóleg a koncentrált oldatok). Az erősen bázikus injekciók akár szövetelhalást is okozhatnak. Nem ritka olajgranuloma kifejlődése.

A harmadik parenteralis gyógyszerbeviteli mód a subcutan adás. NSAID-készítmények esetében ezt nem alkalmazzuk.

A parenteralis alkalmazás nagy előnye, hogy a gyógyszer egyenesen a keringésbe jut. Intramuscularis és subcutan bevitel esetében a gyógyszer fizikokémiai tulajdonságai befolyásolják a gyógyszer felszívódását, általában a felszívódás gyors és jelentős mértékú. A parenteralis alkalmazás további előnye, hogy gastrointestinalis mellékhatásai elkerülhetőek [60].

\section{A transdermalis gyógyszerbevitel}

A transdermalis gyógyszerbevitel korszerú, a peroralis beviteli módhoz képest több előnnyel járó terápiás lehetőség. A külsődlegesen alkalmazott krémek és kenőcsök általában nem szívódnak fel, hanem helyi hatást idéznek elő. Ezen gyógyszerforma esetén a felszívódás a bőrön keresztül a kezelni kívánt területhez, illetve régióhoz való eljutást jelenti. A transdermalis tapaszok a bőrfelszínen gyógyszerdepóként szolgálnak. A bőr felületéről való felszívódást elősegíti a nagy felszín, a jó vér- és nyirokellátás, ugyanakkor gátolja az elszarusodó laphám. A külsődlegesen alkalmazott krémek és kenőcsök helyi hatást idéznek elő az alkalmazás lokalizációjának megfelelő szövetekben, a plazmába való eljutásuk mértéke szerény. A helyi vérbőség, amely már említésre került, felszívódást potencírozó tényező - a metil-szalicilát tartalmú tapasz esetében ez is hozzájárul a jó abszorpcióhoz és terápiás hatáshoz [61]. A kapszaicin, mint bizonyítottan helyi hatással bíró fájdalomcsillapító, több tényező mellett szintén a lokális keringésfokozás révén fejti ki hatását $[39,62]$.
A nagy lipid-víz megoszlási hányadosú molekulák felszívódása jelentős lehet a bőrön keresztül. A felszívódást még fokozni lehet dörzsöléssel (helyi vérbőség), párolgásgátló anyagok alkalmazása révén, mint például zárótapasz felhasználásával. Zárótapasz hatására akár 50\%-kal megnőhet a hámsejtek víztartalma, a duzzadás a sejtek fellazulását eredményezi. A bőrfelszívódás a tapaszok megjelenésével vált igazán terápiás értékú eljárássá, amely előnyös alternatívája is lehet a peroralis NSAIDokkal, illetve analgetikumokkal való kezelésnek. A tapaszok további előnyei közé tartozik, hogy kényelmesen alkalmazhatók, a felszívódás jól szabályozható, túladagolásnál a tapaszt el lehet távolítani. Léteznek programozott kioldódású gyógyszerek - ez úgy érhető el, ha a hatóanyagot gyantához, abszorbenshez kötik. A tapaszok alkalmazásával elkerülhető a változó vérkoncentráció. A bőrön keresztül liposzómákhoz kötött gyógyszereket is be lehet juttatni. Ebben az esetben a szer gyorsan felszívódik, és a bőrben képez raktárakat. Hátránya, hogy túladagolás esetén nem lehet megszüntetni a további beáramlást.

Több transdermalis nem szteroid gyulladásgátló gyógyszer bevitelét lehetővé tevő tapasz is forgalomban van (3. táblázat). Diclofenacalapú gyógyszeres tapasz $140 \mathrm{mg}$ diclofenac-epolamin hatóanyagot tartalmazó fájdalomcsillapító és gyulladáscsökkentő hatású készítmény. A másik gyakran használt készítmény, amely igen kedvező tulajdonságokkal rendelkezik, a ketoprofen hatóanyagot tartalmazó speciális tapasz. A tapasz hatásához hozzájárul, hogy ez és a metil-szalicilát-tartalmú tapasz is gélalapú és vízmentes készítmények, a percutan abszorbció, a szöveti penetráció elősegítésére és az adagolás tökéletesítésére szolgáló úgynevezett TDDS (transdermal drug delivery system) technológiával készültek. A ketoprofen és a metil-szalicilát is olajos komponensben oldottan helyezkedik el a mikrorekeszes struktúrában. A technológia lehetővé teszi, hogy a hatóanyag fokozatosan szabaduljon fel a polimer mikrorekeszes struktúrájából és biztosítsa a megfelelő tapadást.

3. táblázat $\mid \begin{aligned} & \text { Leggyakrabban használt fájdalom- és gyulladáscsökkentő } \\ & \text { tapaszok }\end{aligned}$

\begin{tabular}{llll}
\hline Hatóanyag & Kiszerelés & $\begin{array}{l}\text { Javasolt } \\
\text { adag }\end{array}$ & Felírhatóság \\
\hline Diclofenac & $5 \times$ & Napi $2 \times$ & $\begin{array}{l}\text { Nem } \\
\text { receptköteles }\end{array}$ \\
\hline Diclofenac & $2 \times, 5 \times, 10 \times$ & Napi $2 \times$ & $\begin{array}{l}\text { Nem } \\
\text { receptköteles }\end{array}$ \\
\hline Ketoprofen & $\begin{array}{l}4 \times, 7 \times \text { TDDS- } \\
\text { technológia }\end{array}$ & Napi $1 \times$ & Receptköteles \\
\hline $\begin{array}{l}\text { Metil-szalicilát }+ \\
\text { levomentol }\end{array}$ & $2 \times, 20 \times$ & Napi $2 \times$ & $\begin{array}{l}\text { Nem } \\
\text { receptköteles }\end{array}$ \\
\hline $\begin{array}{l}\text { Metil-szalicilát }+ \\
\text { levomentol }\end{array}$ & $\begin{array}{l}5 \times \text { TDDS- } \\
\text { technológia }\end{array}$ & Napi $2 \times$ & $\begin{array}{l}\text { Nem } \\
\text { receptköteles }\end{array}$ \\
\hline
\end{tabular}

TDDS = transdermal drug delivery system technológia 
A tapaszok mellékhatásai tekintetében a leggyakoribb nemkívánatos esemény a viszketés. Kevésbé gyakori az égető érzés a bőrön, a bőr kipirosodása, illetve a helyi kiütés. Ez a kezelés azonnali megszakítását indokolja. A ritka mellékhatások közé tartoznak az allergiás bőrreakció, a helyi oedema és a fényérzékenység. Nagyobb a rizikó, amennyiben a beteg asztmában vagy krónikus csalánkiütésben szenved, vagy gyulladáscsökkentő gyógyszerekre is érzékeny.

A transdermalis alkalmazás egyértelmú előnyei a következőkben foglalhatók össze:

- A lokális NSAID-ok mellett jóval alacsonyabb plazmaszint alakul ki a per os alkalmazott NSAID-okhoz képest $(2-10 \%)$.

- Célzottan alkalmazható a felületesen fekvő ízületek és egyéb képletek fájdalmai esetén. A helyi szövetekben magas koncentráció érhető el.

- A lokálisan alkalmazott NSAID-terápiában az alacsony plazmaszint mellett kevesebb a szisztémás mellékhatás (gastrointestinalis, cardiovascularis, nephrotoxicitas) a per os NSAID-okhoz képest.

Mindezek alapján a különböző gyógyszerformák előnyeit és hátrányait összehasonlítva, az alábbi következtetések vonhatók le:

Gél esetében a dozírozás nem pontos. Nem tudjuk, mennyi a bőrre felvitt gyógyszermennyiség, mennyi törlődött le és mennyi szívódott fel. Gélhez, illetve krémhez képest a tapasz pontos dozírozást biztosít. Megfelelő mennyiségú hatóanyagot juttat be. Folyamatos felszívódást biztosít a tapasz, a fedés által is segíti a hatóanyag felszívódását. Fontos compliance-tényező, hogy a beteg nem keni össze a kezét és a ruháját, ha tapaszt használ. Nem kell újra alkalmazni napközben, nem kell többet magával vinnie.

Az egyéb tapaszokhoz képest a TDDS-technológia jobb permeabilitást biztosít, mind a metil-szalicilátot, mind a ketoprofent kiváló percutan abszorpció jellemzi. Compliance-javító tényező, hogy a tapasz rugalmas, hajlékony, pontos illeszkedést biztosít, jól tapad, mozgás során sem jön le, nem szükséges rögzíteni. Az oralis NSAID-okhoz képest a tapaszok akár hatékonyabbak is lehetnek, magasabb koncentráció alakul ki a gyulladt szövetben. A felhelyezés után a metilszalicilált-levomentol hatóanyagú tapaszok szinte azonnal direkt fájdalomcsillapító hatást fejtenek ki. Egyes, fóleg a szalicilkomponensű tapaszok, lokálisan bizseregtető érzést okoznak, amely hozzájárul a fájdalomcsillapító effektushoz. A tapaszok biztonságosságát az adja, hogy kisebb plazmakoncentrációt okoznak és ezáltal kevesebb a mellékhatás. Kedvezően befolyásolja a compliance-t, hogy a ketoprofentartalmú tapasz 24 órás hatású, naponta csak egyszer kell felhelyezni. A diclofenac- és metil-szaliciláttartalmúakat 8-12 órás hatás miatt naponta kétszer javasolt alkalmazni. A metil-szalicilát-tartalmú tapasz terápiás hatásához a levomentol az endogén opioid receptorok aktiválásán keresztül közvetített helyi fájdalomcsillapító hatásával is hozzájárulhat [61, 63-67].

\section{A nem szteroid gyulladáscsökkentők potenciális nemkívánatos hatásainak kitett kockázati betegcsoportok}

A nem szteroid gyulladáscsökkentők nemkívánatos hatásai alapvetően hatásmechanizmusukkal függnek össze, a prosztaglandinoknak a sokrétû, a szervezet homeosztázisát biztosító hatásának csökkentése, kikapcsolása miatt. A keringés, véralvadás, bronchustónus, gyomornyálkahártya-védelem egyensúlyának felborulása elsősorban azokat fenyegeti, akiknél ezek élettani okok vagy más gyógyszerelés miatt határértéken vannak. Ezenkívül, mint a legtöbb gyógyszer esetében, lebontásuk és kiválasztásuk során igénybe veszik a máj és a vesék kapacitását. Tehát az időskorúak és az indikáción túl más betegségekben szenvedők számára a nem szteroidkezelés kockázatosabb. Számításba kell venni, hogy az indikációk többnyire krónikus betegségek tünetei és tartós gyógyszeradást indokolnak. A gyermekkor elsősorban gyógyszerválasztási és -adagolási figyelmet igényel.

Az időskorúak (definíciószerúen a 65 évesnél idősebbek) kockázatait differenciáltan kell megítélni. Megőrzött élettani funkciók mellett a standard gyógyszerelés csak kevéssé jelent többletkockázatot. A vese- és májmüködés beszúkuülése, a testtömeg csökkenése, a fájdalomérzékelés megváltozása az élettani eredetű kockázatokat képviselik. A mentális funkciók csökkenése az együttmüködés, a gyógyszerek ismerete és adagolása, a mellékhatások felismerése terén jelent veszélyeket. A kritikátlan vagy hibás tájékoztatáson alapuló öngyógyszerelés, a környezet és a gyógyítóteam esetleges téves tájékoztatása is szerepel a felismerendő kockázatok között. Az idős beteg ellátóinak viszont tisztában kell lennie ezekkel a kockázatokkal, megkülönböztetett figyelemmel kell kísérnük az idős beteget, aktívan tájékozódniuk kell a beteg korlátai felől és el kell látniuk a biztonságos gyógyszerszedéshez szükséges információkkal [68-70].

A multimorbid, többféle gyógyszert szedő, szteroidkezelésben, antikoaguláns terápiában részesülő, krónikus máj-, vese-, gyomor- és érbetegek életkoruktól függetlenül kockázati betegnek tekintendők [71].

Gyermekeknél az időleges tüneti nem szteroidkezelés dominál, eseti fájdalmak, sérülések, láz, kisebb mútétek kapcsán. A kezelés leggyakrabban hagyományos COX1-gátlókkal történik. Az életkorhoz, illetve testsúlyhoz adaptált adagolásban, megfelelő indikációkban alkalmazva a nem szteroidok hatásosak, jól tolerálhatóak és biztonságosak. Gyermekkori alkalmazásra a nem szteroidok korlátozottan vannak törzskönyvezve (a leggyakoribb a naproxen, az ibuprofen, az indometacin, a meloxicam és a celecoxib), és kevés készítmény áll rendelkezésre folyékony, illetve ízesített formában. Adagolásukra vonatkozóan az alkalmazási elóírásokban foglaltakat és a nemzetközi gyermekreumatológiai szervezet (Pediatric Rheumatology International Trials Organisation PRINTO) ajánlásait kell figyelembe venni $[72,73]$. A gyermekkori mútétek (leggyakrabban fogászati beavat- 
kozás és tonsillectomia) kapcsán a nem szteroidokkal történő posztoperatív fájdalomcsillapítás nem jár a véralvadás megváltozásával és utóvérzéssel $[74,75]$.

\section{A nem szteroid gyulladáscsökkentők biztonságossága}

\section{NSAID-kezelés kapcsán a megfelelo" \\ gyógyszerválasztás és a potenciális szövődmények megelózése céljából alkalmazott kiegészitó terápiák növelik a betegbiztonságot}

A klasszikus NSAID-okról több évtizede ismert, hogy tartósan, teljes adagban alkalmazva vese- és májkárosító hatásuk van, és potenciálisan súlyos, akár életet veszélyeztető mellékhatásként gyomor- vagy nyombélfekélyt, következményes perforációt és vérzést okozhatnak [76]. A ciklooxigenáz-2-(COX-2-) gátlók kifejlesztésével igazoltan csökkenthető volt a gyomor-bél rendszeri szövődmények aránya, de a klinikai vizsgálatok igazolták, hogy ezt a gyógyszercsoportot nagy dózisban alkalmazva nő a szív- és érrendszeri komplikációk gyakorisága, emellett a klasszikus NSAID-okhoz hasonló nephro- és hepatotoxicus hatással is bírnak [77]. Tovább nehezíti a megfelelő gyógyszerválasztást, hogy a klasszikus NSAID-ok egy részénél is számolni kell cardiovascularis (CV) szövődményekkel, amint ez az elmúlt néhány évben nyilvánvalóvá vált [78].

Az egyes kórképek terápiás ajánlásai az NSAID-kezelés kapcsán hangsúlyozzák a megfelelő gyógyszerválasztás és szükség szerinti kiegészítő kezelések alkalmazásának fontosságát, ugyanakkor nagyszámú beteget magába foglaló felmérések igazolták, hogy a felírásoknak csak 30-50\%-a felelt meg az ajánlásban foglaltaknak [79$81]$.

\section{Az NSAID-ok interstitialis nephritist és hyperkalaemiát is okozhatnak. Hosszabb ideig történó alkalmazásuk papillaris necrosissal és krónikus veseelégtelenséggel járhat}

A PGE-2 és PGI-2 prosztaglandinok hatékony vasodilatatorok, amelyek a vesemedullában, illetve -glomerulosában szintetizálódnak és a vese vérátáramlásának, valamint só- és vízkiválasztásának szabályozásában vesznek részt. A renalis prosztaglandinszintézis-gátlás nátrium-visszatartást, csökkent vese-vérátáramlást és veseelégtelenséget eredményezhet, különösen az olyan betegekben, ahol ez vasoconstrictor hatású katecholaminok és angiotenzinII-felszabadulással társul (például pangásos szívelégtelenségben, cirrhosisban).
Az NSAID-ok növelik a jelentös cardiovascularis események rizikóját, függetlenül attól, hogy a betegnél fennáll-e koszorúér-betegség

Nagyszámú, 280 tanulmány metaanalízise igazolta, hogy a COX-2-gátlók és a diclofenac mintegy harmadával növelik a jelentős vascularis események (relatív rizikó [RR] 1,37 és 1,41) és háromnegyedével a jelentős coronariatörténések számát (RR 1,76 és 1,70). Ibuprofen mellett szintén szignifikánsan emelkedett a coronariaeredetú jelentős események aránya (RR: 2,22), ugyanakkor nem volt szignifikáns a vascularis betegségek rizikójának növekedése [82]. Egy közel 60 000, korábban myocardialis infarctuson átesett beteget magába foglaló regiszter adatai azt igazolták, hogy mind a mortalitás, mind az ismétlődő myocardialis infarctus gyakorisága nagyobb az NSAID-ot alkalmazók körében. A halálozás rizikóját 1,5-2,8-szeresre, míg az újabb szívinfarktusét 1,252,63-szorosra növelték az NSAID-ok [83]. A fenti szövődmények előfordulása nem volt az NSAID-ok rövid távú alkalmazásával csökkenthető, mivel már egy-két hetes vagy egyes szereknél egy hónapos szedés után is emelkedett rizikó volt észlelhető [84]. Az NSAID-ok közül a diclofenac szedéséhez társult leggyakrabban jelentős cardiovascularis esemény, míg ez az arány a naproxen esetén volt a legkisebb [85]. Az Európai Gyógyszerügynökség (EMA) humán gyógyszer-koordinációs munkacsoportja (CMDh) kezdeményezésére állásfoglalás született az ibuprofen és dexibuprofen dózisfüggő cardiovascularis kockázatáról. Több tanulmány adata alapján megállapították, hogy ezek nagyobb (napi 2400, illetve $1200 \mathrm{mg}$ ) adagjainak csak kisebb mértékü cardiovascularis kockázata van. Ez más nem szteroid gyulladáscsökkentókével (ideértve a COX-2-gátlókat és a diclofenacot) összemérhető, de kisebb adagban a naproxenhez hasonló. Ezért a napi legfeljebb 1200 mg (dexibuprofennél értelemszerüen $600 \mathrm{mg}$ ) adag mellett a kisebb kockázat sem áll fenn, így a magasabb kockázati fokú betegeknek naproxen, illetve az ibuprofen/dexibuprofen alacsonyabb napi adagjai ajánlottak [82, 86-88]. Megemlítendő, hogy az egyes NSAID-ok kapcsán jelentkező cardiovascularis rizikó pontos meghatározása a PRECISION study adatainak közeljövőben várható publikálásától várható. Ez az első, cardiovascularis rizikó felmérésére tervezett tanulmány, amely a celecoxib, ibuprofen és naproxen ilyen célzatú összehasonlítására szolgál [89-91].

\section{Az NSAID körültekintés nélküli adása növeli a stroke gyakoriságát}

Nagy betegszámú követéses vizsgálatok során az ischaemiás stroke gyakoriságának hagyományos NSAID-ok szedése esetén 1,7-szeres, COX-2-blokkolók esetén pe- 
dig 4,5-szeres növekedését észlelték alacsony cardiovascularis rizikójú egyének körében is. Ebben a kohorszban a naproxen és a rofecoxib szedéséhez társult magasabb rizikó, míg az ibuprofen és a diclofenac esetén az emelkedés nem volt szignifikáns mértékű [92]. Egy másik regiszter adatai szerint a relatív rizikó 1,6-szeres volt igazolt atherosclerosisban vagy többszörös rizikófaktorokkal bíró egyéneknél [93]. A vascularis eredetű halálozás szignifikánsan gyakoribb volt a coxibok és a diclofenac, nem szignifikánsan emelkedett ibuprofen alkalmazása mellett, míg a naproxennek nem volt igazolható ilyen mellékhatása [82, 90, 91].

\section{Az NSAID-ok szedése közvetve és közvetetten is hozzájárul a szivelégtelenségben szenvedōk állapotának a romlásához}

A veseglomerulusok afferens arterioláinak vasoconstrictiója révén, amelyet az NSAID-ok a vese prosztaglandinszintézisének gátlásával hoznak létre, a szervezetben nátrium- és folyadékfelhalmozódás alakul ki, ami a perifériás rezisztencia fokozódásával együtt tovább rontja a szív pumpafunkcióját. Emellett a szívelégtelenség etiológiájában fontos szerepet játszó coronariaatherosclerosis és hypertonia romlása révén az NSAID-ok másodlagosan is hozzájárulnak a szívelégtelenség romlásához. Az NSAID-ok a szívelégtelenség kezelésében fontos szerepet játszó diuretikumok hatását mérséklik, illetve az angiotenzinkonvertálóenzim-inhibitorokkal (ACE-gátlók) vagy angiotenzinreceptor-blokkolókkal együtt alkalmazva jelentősen képesek csökkenteni a glomeruláris filtrációs nyomást és a filtrációt, mivel az utóbbiak által okozott efferens arteriola vasodilatatiója mellett az NSAID-ok szúkítik az afferens arteriolákat. Elsősorban idősebb korban a hagyományos és COX-2-szelektív NSAID-ok egyaránt növelik a szívelégtelenség miatti kórházi felvételt és halálozást [94-96].

Egy 107 ezer beteget magába foglaló regiszterben a legnagyobb rizikót a diclofenac és a COX-2-blokkolók alkalmazása jelentette, az alacsony dózisú iboprofen és naproxen nem növelte a rizikót, míg utóbbi szereket nagy dózisban alkalmazva hatásuk - más NSAID-okéhoz hasonlóan - kedvezőtlen volt [97]. Az egyes NSAID-ok kórházi felvételt szülkségessé tevő szívelégtelenséget okozó hatását elemző metaanalízis eredménye szerint a coxibok, a diclofenac, az ibuprofen és a naproxen egyaránt mintegy duplájára emeli a rizikót $[82,90,91]$.

\section{Az NSAID-ok szedése vérnyomás-emelkedést okozhat}

Metaanalízisek tanúsága szerint átlagosan $5 \mathrm{Hgmm}$ körüli szisztolés vérnyomás-emelkedést okoznak az NSAID-ok, s ez a jelenség elsősorban az idősebb korosz- tályban vagy korábban is hypertoniában szenvedók esetén a legnyilvánvalóbb [98-100]. Vérnyomás-emelkedést már egydózisnyi NSAID éppúgy képes kiváltani, mint a néhány hetes szedés [101, 102]. A jelenség magyarázatául a szívelégtelenség romlásában is szerepet játszó folyadék- és nátriumretenció mellett érszűkítő és értágító prosztaglandinok termelődésében kialakuló megbomló egyensúly szolgál. Az NSAID-ok az ACEgátlók és ARB-k, valamint a béta-blokkolók hatását csökkentik, míg a kalciumcsatorna-blokkolót vagy diuretikumot szedők vérnyomását kevésbé befolyásolja az egyidejü NSAID-szedés [90, 91, 99, 102].

\section{Az NSAID-ok növelhetik a pitvarfibrilláció elöfordulását}

Már néhány hetes NSAID-szedés után is növekszik a pitvarfibrilláció elsősorban az idősebb és szívelégtelenségben szenvedő egyének körében [103, 104]. Bár egy 325 ezres betegszámú regiszter adataiból igazolódott, hogy az egyes NSAID-ok egyformán növelik a pitvarfibrilláció előfordulását [105], mások COX-2-blokkolók esetén nagyobb rizikót figyeltek meg, különösen idült obstruktív légzőszervi betegek vagy veseelégtelenségben szenvedők körében [103, 104]. A ritmuszavar kiváltásában legnagyobb valószínűsége az NSAID okozta folyadékretenciónak van, amely beszúkült vesefunkció vagy szívelégtelenség esetén még inkább hajlamosít pitvarfibrilláció létrejöttére $[90,91]$.

\section{Az NSAID-ok befolyásolják az acetilszalicilsav thrombocytaaggregáció-gátló hatását}

Annak ellenére, hogy az ASA irreverzibilisen kapcsolódik a COX-1 enzimhez, az NSAID-ok egyidejü alkalmazás esetén kompetitíven csökkentik az ASA kötődését és csökkentik thrombocytaaggregáció-gátló hatását, amelyhez a COX-1 enzim legalább 95\%-os gátlása szükséges [106]. Az ibuprofen bevétele két órával az ASA alkalmazása előtt csökkenti az utóbbi tromboxán-B2-szintéziscsökkentő, ezáltal thrombocytaaggregáció-gátló hatását, míg fordított sorrendben kétórás időközökkel használva a gyógyszereket, ilyen hatás nem volt észlelhető [107]. Tartósan ASA-t szedők körében a diclofenac évi legalább 60 napon át történő alkalmazása növelte a myocardialis infarctus rizikóját, szemben a csak ASA-t szedőkkel [108]. In vitro vizsgálatok igazolták, hogy a coxibok nem befolyásolják jelentősen az ASA thrombocytaaggregáció-gátló hatását [109], amely jelenséget ischaemiás szívbetegségben szenvedőkben is megerősítettek [110], ugyanakkor a coxibok szedése kapcsán emelkedett cardiovascularis rizikó képes kioltani ezt a kedvező hatást $[90,91]$. 
Az NSAID-ok önmagukban is növelik

a gyomor-bél rendszeri vérzések számát, amely egyidejüleg fennálló rizikófaktorok esetén még inkább fokozódik

Az NSAID-ok szedése mintegy 2-4-szeresére növeli a súlyos gyomor-bél rendszeri szövődmények, ezen belül is az ulcusképződés, a vérzés és a perforáció veszélyét. Azok az egyének tekinthetók leginkább veszélyeztetettnek gastrointestinalis szempontból, akiknek anamnézisében fekélybetegség szerepel (akár járt szövődménnyel, akár nem), 65 év feletti életkorúak, párhuzamosan kis dózisú aszpirin- vagy antikoaguláns kezelésben részesülnek vagy Helicobacter pylori-fertőzöttek [111]. Egy közel 800 ezer beteget magába foglaló metaanalízisben legalább négynapos NSAID-szedés a súlyos felső gastrointestinalis szövődmények (perforáció, ulcus, vérzés) valószínúségi hányadosát randomizált, kontrollált vizsgálatokban 5,36-szorosára, kohorszvizsgálatokban 2,7-szeresére, míg eset-kontrollos tanulmányokban háromszorosára növelte [112]. NSAID-szedés mellett jelentkező - alsó és felső szakaszt is magába foglaló - gastrointestinalis mellékhatások miatti kórházi felvételek száma 121,9/100 ezer betegév volt [113], s az NSAID-szedés kapcsán kialakult vérző fekély mortalitása 3,8-11\%-osnak adódott $[114,115]$. Szemben a cardialis és vascularis rizikók többségével, a felső gyomor-bél rendszeri vérzés rizikója egyértelmúen függ az NSAID dózisától és alkalmazási idejétól. A vérzés és perforáció veszélye az alacsony dózisú ibuprofen szedése esetén volt a legalacsonyabb, de így is kétszeres rizikót jelentett az NSAIDot nem szedőkkel összevetve, míg a diclofenac és naproxen esetén 3-4-szeres relatív rizikó volt észlelhetó. Hasonló eredményt adott az obszervációs vizsgálatok metaanalízise is, amely szerint 2 alatti relatív rizikóval járt az aceclofenac, a celecoxib és az ibuprofen szedése, míg 2-4 közötti értékkel bírt a diclofenac, a meloxicam és a nimesulid, 4 feletti relatív rizikót okozott a naproxen, az indometacin és a piroxicam [116].

A szelektív-specifikus COX-2-gátló szerek a klasszikus NSAID-okhoz képest körülbelül 50\%-kal csökkentik a súlyos tápcsatornai szövődmények (vérzés, perforáció, stenosis) kockázatát. Mivel azonban nem fejtenek ki thrombocytaaggregációt gátló hatást, a cardiovascularis rizikóval rendelkezó betegek esetében a coxibok alkalmazása növelheti a cardiovascularis események (myocardialis infarctus) lehetőségét.

A rendelkezésre álló adatok alapján úgy túnik, hogy a betegek körülbelül 20\%-ában a cardiovascularis kockázat miatt a coxibok mellett kis dózisú aszpirin szedésére is szükség van, ilyenkor viszont a gasztroprotektív hatás gyakorlatilag megszúnik. Ebben a betegcsoportban vélhetően a coxib-aszpirin kombináció mellé további gasztroprotekcióra (elsősorban PPI-kezelésre) is szükség lehet.

\section{A K-pitamin-antagonisták és a célzott antikoagulánsok tovább növelik az NSAID okozta vérzés rizikóját}

Xa faktor vagy direkt trombininhibitor adása esetén az egyidejúleg szedett NSAID mintegy négyszeresére növeli a vérzéses komplikációk rizikóját [117], a célzott antikoagulánsokat elemző klinikai vizsgálatok post-hoc analízise ezeknél a szereknél a warfarinnal összevethető rizikónövekedést tapasztalt [118, 119].

\section{Az NSAID-ok az alsó gastrointestinalis traktusban kialakuló nemkívánatos eseményekért is felelösek}

Az 1990-es évek eleje óta ismert, hogy az NSAID-szedés kapcsán nyálkahártya-károsodás alakulhat ki az alsó gastrointestinalis traktusban is, amely vérzéshez, perforációhoz és diverticulumbetegséghez vezethet [120]. Videoendoszkópos vizsgálatok igazolták, hogy az NSAID-szedők 75\%-ában alakul ki nyálkahártya-sérülés a distalis gastrointestinalis traktusban, amely a vékonybél proximalis szakaszán nyálkahártya-károsodással, az ettől distalisabb szakaszon többnyire fekélyképződéssel jellemezhető [121]. Ezek - szemben a felső szakaszon kialakult szövődményekkel - nem előzhetők meg protonpumpagátlók adásával, mivel a savas $\mathrm{pH}$ kialakulásukban nem játszik szerepet, sőt akár kedvezőtlen hatásúak is lehetnek dysbiosis kialakításával [122]. A hagyományos és COX-2-szelektív NSAID-ok alsó gastrointestinalis traktusra kifejtett kedvezőtlen hatásait összehasonlítva megállapítható volt, hogy a coxibok ritkábban okoznak vastagbél-károsodást, amely hatás akkor is fennmarad, ha protonpumpagátlókkal együtt alkalmazzák azokat [123, 124].

\section{Gyulladásos mozgásszervi kórképekhez akcelerált atherosclerosis társul, és az NSAID-ok tovább növelhetik a thromboticus események gyakoriságát}

Közismert, hogy a gyulladásos autoimmun kórképek (rheumatoid arthritis, spondylitis ankylopoetica és arthritis psoriatica) felgyorsult érelmeszesedéssel társulnak [125]. Klinikai vizsgálatok metaanalízise igazolta, hogy rheumatoid arthritisben az NSAID-ok alkalmazása növelte a cardiovascularis események rizikóját (RR: 1,18 ), de ez nagyrészt az azóta a piacról kivont rofecoxib hatásának volt tulajdonítható [126]. Arthritis psoriaticában az NSAID-ok esetleges mellékhatásairól releváns közlemények nem állnak rendelkezésre. Spondylitis ankylopoeticában az NSAID-okat tartósan szedik a betegek. A cardiovascularis események gyakorisága egy távol-keleti regiszter adatai szerint coxibokkal már rövid távon is csökkenthető, de hosszú távon alkalmazva a hagyomá- 
nyos NSAID-ok is csökkentik a cardiovascularis események gyakoriságát [127, 128], amelynek magyarázatául a tartós gyulladáscsökkentő hatás szolgál.

\section{Az NSAID-ok bronchospasmust és asthmás rohamot vagy egyéb túlérzékenységi reakciót is kiválthatnak}

Rizikófaktornak számít a kórtörténetben szereplő asthma bronchiale, szénanátha, orrpolip, valamint a krónikus obstruktív légúti megbetegedés, egyéb gyógyszerek által kiváltott allergiás reakciók, például bőrkiütések, viszketés, urticaria. Ennek hátterében az áll, hogy az NSAIDok mellékhatásaként az arachidonsav-kaszkád leukotriének irányába történő áttolásával hörgőszúkületet okozhatnak.

\section{Az osteoarthritises betegek - elsösorban társuló betegségeik kapcsán - fokozottan veszélyeztetettek NSAID szedésekor}

Egy 17 ezer osteoarthritises beteget magába foglaló regiszter adatai alapján a betegek $60 \%$-a gastrointestinalis szempontból magas rizikójúnak bizonyult, míg 32\%-uknak korábbi cardiovascularis eseménye zajlott, és mintegy ötödük nem megfelelően kontrollált hypertoniában szenvedett [128]. Így az osteoarthritis önmagában nem jelent fokozott rizikót az NSAID-ok szedése szempontjából, de az ebben szenvedók, a társuló betegségeik miatt, fokozottan veszélyeztetett betegcsoportnak számítanak.

\section{A transdermalisan alkalmazott NSAID-ok mellékhatásai}

A fotoszenzitizáció-fototoxicitás, illetve kontakt-fotokontakt dermatitis a lokálisan alkalmazott tapaszok mellékhatásai közül az egyik relatíve gyakori nemkívánatos jelenség. A ketoprofen degradációs termékek nagyobb mértékben allergizálnak, mint az eredeti hatóanyag. Emiatt UV-védelem szükséges az alkalmazás után! Az alkalmazási előiratban is szerepel, hogy ha a ketoprofennel kezelt bőrfelületeket napsugárzás (borult idő esetén is) vagy UV-A-sugárzás éri, az potenciálisan súlyos bőrreakciókat (fényérzékenység) okozhat. Ezért szükséges, hogy a fényérzékenység elkerülése érdekében ruházattal védje a beteg a kezelt bőrfelületet a kezelés ideje alatt és az azt követő két hétben. A kezelés ajánlott időtartamát nem szabad túllépni, mivel a kontakt dermatitis és fényérzékenység kockázata a kezelés ideje alatt növekszik. A ketoprofen a vérképző rendszeri rendellenességekben, szisztémás lupus erythematosusban, illetve kevert kötőszöveti betegségben szenvedő betegeknél elővigyázatossággal alkalmazandó. Hasonló mellékhatásprofilja van a diclofenactartalmú tapaszoknak is.
A diclofenactartalmú tapasz metil- és propil-parahidroxibenzoátot tartalmaz, amely (esetleg késleltetett) allergiás reakciót okozhat. A propilénglikol a bőrt irritálhatja. Diclofenac esetében is a kezelt felületen közvetlen napfény vagy a szolárium fénye fokozhatja a fotoszenzibilizáció veszélyét.

Bár szisztémás hatása az összes tapasznak rendkívül csekély, nagy körültekintéssel alkalmazzuk vese-, szív-, májbetegségben szenvedők, illetve olyan betegek esetén, akiknek anamnézisében peptikus fekély, a belek gyulladásos megbetegedése vagy vérzékenység szerepel.

A nem szteroid gyulladáscsökkentőket különösen óvatosan kell alkalmazni idősebb emberek esetében, akiknél a nem kívánt mellékhatások gyakorisága magasabb.

Asztmában és krónikus rhinitisben szenvedó betegek esetében nagyobb az acetilszalicilsavra és/vagy NSAIDokra való allergia kockázata, mint a népesség többi részében.

\section{A multidiszciplináris szemléletü fájdalomambulanciák lehetôségei a krónikus, regionális mozgásszervi fájdalom ellátásában}

A krónikus fájdalom csillapításával foglalkozó önálló tudományág nagyon fiatal, alig 50-60 éves múltra tekint vissza. Az első multidiszciplináris szemléletú fájdalomközpontot John Bonica, a Washingtoni Egyetem aneszteziológusprofesszora hozta létre az Amerikai Egyesült Államokban az 1950-es évek elején. A modell a '60-as évek végére terjedt el az Amerikai Egyesült Államokban, majd a '70-es, '80-as évekre széleskörűen Európában, Ausztráliában, Japánban és Kanadában is. A multidiszciplináris fájdalomközpontok kezelési modelljének középpontjában a fájdalmat megélő beteg áll. A fájdalmat kiváltó okok feltárása után a fájdalom és a társult problémák újraértékelése, az eddigi kudarcok elemzése mellett személyre szabott, multimodális kezelésre van szükség, amelyben a beteg aktív részvételének, felelősségének hangsúlyozása mellett erósíteni kell annak pozitív gondolkodását is. Alapvetô cél tájékoztatni a beteget és hozzátartozóit a fájdalom lehetséges okairól, annak szervi hátterérôl és a pszichés folyamatokról. Támogatni kell a reális célok megvalósításában, segíteni az aktív életvitel és a munkavégzés visszaállításában, a szabadidő hasznos eltöltésében. Fontos a rendszeres kontroll, és ha szükséges, a kezelést újra kell értékelni és új stratégiát kell kialakítani.

A fájdalomambulanciák középerős, erős krónikus fájdalmakkal, illetve azok akut fellángolásaival foglalkoznak, s ritkán kezelnek enyhe akut vagy krónikus fájdalmakat. A mozgásszervi fájdalmak differenciáldiagnosztikai újraértékelésében (malignus tumorok kizárása) és a gerinceredetû, krónikus fájdalmakban tudnak hatékonyak lenni, mert a terápiás lehetőségek széles tárházából választhatnak. Az ízületi fájdalmak elsősorban a már operált ízületek fájdalmának oki meghatározásában (hegfáj- 
4. táblázat | A fájdalomambulancia mozgásszervi eredetű, regionális fájdalmakban alkalmazott komplex gyógyszerterápiás eljárásrendje

\section{1. Átmeneti regionális mozgásszervi fájdalmi epizódok}

Akut helyi ízületi, izom-, szalag-, egyéb lágyrész-fájdalmak esetén helyi NSAID (tapasz, krém, gél, kenőcs): ketoprofen, diclofenac, acetilszalicilsav; ha nem hatékony, oralis NSAID, elsősorban COX-1, kockázati beteg esetében COX-2-gátló.

2. Arthrosis és a gerinc mechanikus eredetú, radiculopathia nélküli akut fájdalmas epizódjai és a krónikus fájdalom gyógyszeres kezelése a) Fájdalom <VAS 40: minor analgetikumok

Paracetamol reguláris, időre való adása kiegészíthető helyi (tapasz, krém, gél, kenőcs) NSAID-alkalmazással (ketoprofen, diclofenac, acetilszalicilsav), kapszaicin helyi alkalmazásával (alapvetően térd-, kézízületi arthrosisos fájdalmak esetén).

Nem kielégítő hatás esetén peroralis NSAID, gasztroenterológiai, cardiovascularis, renalis szempontok figyelembevételével COX-1/COX-2 gátló +/- PPI-kiegészítéssel.

\section{b) Fájdalom VAS 40-60(70): minor opioidok}

Tramadol reguláris, időre való adása, kiegészítve minor analgetikummal az a) pont szerint, ha szükséges.

Alternatívaként dihydrocodein reguláris, időre való adása +/- minor analgetikum a) pont szerint.

A székszorulás megelözése (laxatínum, étrendi tanácsok, mozgás, bö folyadékbevitel) kötelezö.

\section{c) Fájdalom >VAS (60)-70: major opioidok vagy opiátok}

Oxycodon 5/10/20 mg retard tabletta reguláris, idóre (12 óránként) való adása +/- minor analgetikum $a$ ) pont szerint.

Fentanyl TTS $12 / 25 \mu \mathrm{g} / \mathrm{h}$ tapasz reguláris, időre (72 óránként) való adása +/- minor analgetikum $a$ ) pont szerint.

Ha mütét nem lehetséges, illetve a mütétig, mütét után leépithetô". Kötelezö a székszorulás megelözése (laxatívum, étrendi tanácsok, mozgás, bö folyadékbevitel)! Idös, polypathiás, kis testsúlyú betegeknél fokozatos titrálás! A hatékonyság ellenörzése morphium hydrochloricum sc./im. injekcióval lehetséges, ha nincs ellenjavallata. Fentanyl TTS-sel kezelés nem kezdhetö, ha elötte a beteg nem kapta legalább két hétig a tramadol $400 \mathrm{mg} / \mathrm{d}$ vagy oxycodon $20 \mathrm{mg} / d$ dózisát. Minor opioiddal együtt nem adbató. Szakorvosi javallatra (reumatológus, ortopéd, idegsebész, traumatológus) 90\%-os támogatással háziorvos irbatja. A javaslat az adott hatóanyag-tartalmú gyógyszer egész számú többszörösére adbató!

d) Gyulladásos komponens esetén

Helyi NSAID-kezelés, hatástalansága esetén oralis NSAID/COX-2-gátlók reguláris adása.

e) Neuropathiás komponens esetén

Antikonvulzív szerek (carbamazepin, gabapentin, pregabalin stb.) triciklikus antidepresszánsok (amitrypylin, clomipramin stb.) kis dózisai, B-vitamin-komplex kiegészítő adása javasolt.

f) Osteoporosis talaján kialakult akut csigolyakompresszió

NSAID/COX-2-gátlók oralis adása cardiovascularis, gasztroenterológiai, renalis szempontok figyelembevétele +/- PPI.

$+/-$ minor opioidok korai, reguláris adása.

Centrálisan ható izomrelaxánsok.

Korai intervenció!

Gerincfájdalmak esetén tisztázandó a neurológiai, metabolikus és morfológiai háttér, a fájdalom esetleges gyulladásos jellege (45 éves kor alatti fokozatos kezdet, éjszakai nyugalomban fokozódik, mozgásra javul). Figyelmeztetó neurológiai tünetek (paresis, cauda tünetek) kizárása után, erös fájdalom esetén legfeljebb egy-két napos pibenés, utána aktivizálás ajánlott. Nem kielégitő javulás esetén korán az agresszivebb fokozatra kell áttérni, a fájdalom krónikussá válásának megelözése céljából.

Ízületi eredetü fájdalom esetén gyulladásos rendszerbetegség kezdetének lehetösége tisztázandó.

g) Krónikus degeneratív/metabolikus nagyízületi és gerincfájdalmak

Mint a 2. pont alatti, a fájdalom nagysága szerint súlyozott gyógyszeres kezelések. Amennyiben a fájdalom tartósan nem befolyásolható és neuropathiás/pszichés tünetek jelentkeznek, adjuváns terápiákkal való kiegészítés (antidepresszívumok, antikonvulzánsok) ajánlott.

\section{Gerincbetegségek okozta, radiculopathiával járó fájdalmak}

\section{3/1. Akut, radiculopathiával kísért gerincbetegségek}

Mint a 2. pont alatti, a fájdalom nagysága szerint súlyozott gyógyszeres kezelések, a csatolt figyelmeztetések szem előtt tartásával.

A kezelések hatástalansága esetén korán az agresszívebb fokozatra kell áttérni, a fájdalom krónikussá válásának megelózése céljából. Tisztázni kell a neurológiai és morfológiai hátteret, esetleges későbbi invazín vagy operatín beavatkozás elókészitése céljából.

\section{3/2. Krónikus, radiculopathiával kísért gerincbetegségek}

Mint a 2. pont alatti, a fájdalom nagysága szerint súlyozott gyógyszeres kezelések, a csatolt figyelmeztetések szem előtt tartásával. Indokolt a gyógyszerelést B-vitamin-komplexekkel, centrálisan ható izomrelaxánsokkal és antineuropathiás gyógyszerekkel (duloxetin, pregabalin, gabapentin) adjuvánsként kiegészíteni. Mérlegelni kell intervenciós, illetve késői operatív beavatkozások (gerincstabilizáció, dekompresszió) lehetőségét.

dalom, komplex regionális fájdalom szindróma stb.) kell gondolkodni és azok speciális kezelési lehetőségeiben tudnak segíteni az optimális beavatkozás kiválasztásával. A gyógyszeres kezelés mellett a masszázs, manuálterápia, gyógytorna, TENS, különböző mágneses kezelések, egyéni és csoportos pszichoterápiás módszerek vethetők be. Az invazív módszerek közé tartoznak a különböző injekciók, infúziós kezelések és idegblokádok. Az idegblokádok esetében különbséget kell tenni a diagnosztikus és a terápiás blokád között. Diagnosztikus blokáddal a fájdalmat kiváltó okot (facet ízület, sacroiliacalis ízület [SIJ], szomatikus zsigeri fájdalom elkülönítése stb.) határolják be, terápiás blokáddal pedig kezelik azt. A terápiás idegblokád kémiai anyagokkal (helyi érzéstelenítő stb.), hővel (cryoablatio, termokoaguláció) és pulzáló rádiófrekvenciás kezeléssel (neuromoduláció) végezhető. Gerinceredetû fájdalmak kezelésében a módosított paravertebralis blokád sorozatot, a facet ízületek és az SIJ-k blokádját, a szalagerősítő, úgynevezett proloterápiát, valamint az epiduralis térbe adott gyógyszeres (szte- 
roid stb.) és manipulációs kanülös (neurolysis) kezeléseket alkalmazzák a leggyakrabban.

A fájdalomterápia megválasztásában az IASP (International Association for the Study of Pain) és más nemzetközi fájdalomtársaságok ajánlásainak a hazai feltételekhez való adaptációja az irányadó. A fájdalomambulancia mozgásszervi eredetû, regionális fájdalmakban alkalmazott komplex gyógyszerterápiás eljárását a 4. táblázatban mutatjuk be.

\section{Ajánlások regionális nociceptív eredetú mozgásszervi fájdalmak nem szteroid gyulladáscsökkentőkkel történő fájdalomcsillapító gyógyszeres kezeléséhez}

A szerzők az ajánlásokat a fájdalommenedzselés általános alapelveit, a mozgásszervi rendszerbetegségek jelenségeiból és a regionális mozgásszervi szindrómákból származó fájdalmak kezelésének irányelveit és metaanalíziseit

5. táblázat |Az ajánlások megfogalmazásához és a bizonyítékok értékeléséhez felhasznált irányelvek és metaanalízisek

Reumatológiai és Fizioterápiás Szakmai Kollégium. A gyógyszeres fájdalomcsillapításról és gyulladásgátlásról a reumatológiai betegségekben. Az Egészségügyi Minisztérium szakmai protokollja. Egészségügyi Közlöny 2005; 21: 3532-3541.

Osteoarthritis: diagnosis and treatment. Am Fam Physician 2012; 85: 49-56.

American College of Rheumatology 2012 recommendations for the use of nonpharmacologic and pharmacologic therapies in osteoarthritis of the hand, hip and knee. Arthritis Care Res. 2012; 64: 465-474.

OARSI guidelines for the non-surgical management of knee osteoarthritis. Osteoarthritis Cartilage 2014; 22: 363-388.

Osteoarthritis: Care and management in adults. NICE clinical guideline [CG177]. Issued: February 2014.

Noninvasive treatments for acute, subacute, and chronic low back pain: A Clinical Practice Guideline from the American College of Physicians. Ann Intern Med. 2017; 166: 514-530.

Systemic pharmacologic therapies for low back pain: A systematic review for an American College of Physicians Clinical Practice Guideline. Ann Intern Med. 2017; 166: 480-492.

Pharmacologic therapy for acute pain. Am Fam Physician 2013; 87: 766-772.

Institute for Clinical Systems Improvement. Assessment and management of chronic pain. Updated November 2013. Health Care Guideline. www.icsi.org

Recommendations for the pharmacological management of neuropathic pain: An overview and literature update. Mayo Clin Proc. 2010; 85(3 Suppl): S3-S14.

A consensus statement on the European Society for Clinical and Economic Aspects of Osteoporosis and Osteoarthritis (ESCEO) algorithm for the management of knee osteoarthritis - From evidence-based medicine to the real-life setting. Semin Arthritis Rheum. 2016; 45(4 Suppl): S3-S11.

Interventions available over the counter and advice for acute low back pain: systematic review and meta-analysis. J Pain 2014; 15: 2-15.

Treatment guidelines for the pharmacological management of pain in older persons. Pain Med. 2012; 13(Suppl 2): S57-S66.

Nonsteroidal anti-inflammatory drugs and their effects in the elderly. Aging Health 2012; 8: 167-177.

Pain managament in the elderly: an FDA safe use initiative expert panel's view on preventable harm associated with NSAID therapy. Curr Gerontol Geriatr Res. 2012; 2012: Article ID 196159.

Recommendations for FDA interventions to decrease the occurrence of acetaminophen hepatotoxicity 2008. www.fda.gov/Guidances/UCM 164098 .

Safe use of non-steroidal anti-inflammatory drugs in infants and children. Med Today 2006; 7: 71-73.

Nonsteroidal anti-inflammatory drugs and perioperative bleeding in paediatric tonsillectomy. Cochrane Database Syst Rev. 2013; 7: CD003591.

Nonsteroidal anti-inflammatory drugs: a survey of practices and concerns of pediatric medical and surgical specialists and a summary of available safety data. Pediatr Rheumatol Online J. 2010; 8: 7 .

Tájékoztatás a gyermekkori reumás megbetegedésekról. Gyógyszeres kezelés. https://www.printo.it/pediatric-rheumatology/HU/info/15/link. Topical NSAIDs for acute musculoskeletal pain in adults. Cochrane Database Syst Rev. 2015; 6: CD007402.

Topical NSAIDs for chronic musculoskeletal pain in adults. Cochrane Database Syst Rev. 2016; 4: CD007400.

Efficacy and safety of topical NSAIDs in the management of osteoarthritis: Evidence from real-life setting trials and surveys. Semin Arthritis Rheum. 2016; 45(4 Suppl): S18-S21.

FDA Draft guidance on menthol; methyl salicylate. Revised Oct 2016

Az ajánlásokat alátámasztó bizonyítékok GRADE minősítése (Grading Guide grading recommendations)

1A: erős ajánlás, jó minőségú bizonyíték.

1B: erős ajánlás, közepes minőségű bizonyíték.

IC: erős ajánlás, gyenge minőségú bizonyíték.

2A: gyenge ajánlás, jó minőségű bizonyíték.

2B: gyenge ajánlás, közepes minőségű bizonyíték.

2C: gyenge ajánlás, gyenge minőségü bizonyíték.

Az egyetértés szintje: egyetértő szerzők száma/összes szerző. 
tárgyaló közlemények alapján állították össze. Az ajánlások a centrális, a neuropathiás és a neuropathiás nociceptív fájdalomra vonatkozó eljárásokat csupán a nociceptív fájdalom kontextusában mint adjuváns beavatkozásokat tárgyalják. Az egyes ajánlások minősítése a GRADEmeghatározásokon alapuló fokozatok szerint történt. Az ajánlások alapjául szolgáló tanulmányokat, a minősítés és a szerzók egyetértésének definícióit az 5. táblázat tartalmazza $[31,32,35,37,39,61,62,68-75,129-136]$.

\section{A) ÁLTALÁNOS AJÁNLÁSOK}

\section{A/1. A betegek aktuális fájdalmával és alapbetegségével kapcsolatos ajánlások}

1. A fájdalom kórtörténetét a lehető legpontosabb részletességgel kell rögzíteni (mióta, hol, milyen jelleggel, milyen erősséggel, mi befolyásolja, hová sugárzik ki stb.), és meg kell határozni a fájdalom típusát (nociceptív, neuropathiás, kevert).

A bizonyitékok ereje és minösége: $1 A$. Az egyetértés szintje: $8 / 8$.

2. A fájdalom intenzitását valamely, általánosan használt fájdalommérő skálával (VAS, fájdalom numerikus skála stb.) kell meghatározni.

A bizonyitékok ereje és minösége: $1 A$. Az egyetértés szintje: $8 / 8$.

3. A beteget teljeskörúen fel kell világosítani a fájdalmának lehetséges okairól, azoknak betegségeivel való összefüggéséról, a noninvazív (gyógyszeres, nem gyógyszeres) és az invazív (blokád, műtét stb.) terápia lehetőségeiről, várható hatásairól és kockázatairól.

A bizonyitékok ereje és minôsége: $1 A$. Az egyetértés szintje: $8 / 8$.

4. A terápiás döntéseket a megfelelően tájékoztatott beteggel közösen kell meghozni, a terápiás javaslatok kapcsán figyelembe kell venni a várható anyagi terheket és a beteg egyéni preferenciáit.

A bizonyitékok ereje és minösége: $1 A$. Az egyetértés szintje: $8 / 8$.

5. A betegeket az egyes nem szteroid gyulladáscsökkentőkkel való kezelés előtt a megfelelő kockázatok tekintetében minősíteni kell:

a) Átlagos kockázat (nincs jelentős társult betegség, életkori vagy életviteli kockázat).

b) Magas gyomor-bél rendszeri kockázat (gyulladásos rendszerbetegség, anamnesztikus vagy aktuális vérzés vagy ulceratio, vérzékenység, szteroidkezelés).

c) Magas szív-ér rendszeri kockázat (anamnesztikus infarktus vagy stroke, kezeletlen magas vérnyomás, diabetes, perifériás érbetegség, dohányzás).

d) Magas gyomor-bél rendszeri és szív-ér rendszeri kockázat együttesen.

e) Egyéb, életkori vagy életviteli kockázat (várható compliance).

A bizonyitékok ereje és minösége: $1 A$. Az egyetértés szintje: $8 / 8$.
6. A lokális az elsőként választandó szerek helyi jellegú, illetve egy adott régiót érintő, nem szisztémás gyulladásos mozgásszervi kórkép esetében, elsősorban a lágyrész-eredetû enyhe és mérsékelt fájdalmak kezelésére. A krémek, kenócsök és tapaszok, fóleg a TDDS-technológiával készültek, a biztonságosabb dozírozás, a jobb helyi felszívódás és a szisztémás mellékhatások kockázatának minimalizálása érdekében választandók.

A bizonyitékok ereje és minösége: $1 A$. Az egyetértés szintje: $8 / 8$.

\section{A/2. Akut fájdalmak}

1. Mérsékelt és közepes akut fájdalom esetén - amennyiben lokális kezelés nem jön szóba vagy nem kellően hatásos - acetaminophen (paracetamol) az első választandó peroralis fájdalomcsillapító. Hepatotoxicus hatása miatt kerülni kell a kumulálódást, már rövid időtávon is. Ezt elkerülendő, az egyes adagok közt hosszabb időtartamok szükségesek (legfeljebb négyóránként adandó).

A bizonyitékok ereje és minösége: 1 A. Az egyetértés szintje: $7 / 8$.

2. A COX-1- és a COX-2-gátlók hatásos és biztonságos fájdalomcsillapító gyógyszerek. A COX-2-bénító monoterápia és a COX-1-gátlók gasztroprotektív gyógyszerekkel (PPI) kombinálva azonos valószínúséggel okoznak GI-mellékhatásokat kockázati betegekben, ezért gyógyszerválasztás előtt tájékozódni kell a beteg társbetegségeiről és egyéb gyógyszereléséről.

A bizonyitékok ereje és minösége: $1 A$. Az egyetértés szintje: $8 / 8$.

3. Erôs opioid agonista választandó, ha gyenge opioid, akár acetaminophennel vagy NSAID-dal nem eléggé hatásos a közepes vagy erôs fájdalom esetén.

A bizonyitékok ereje és minösége: $1 A$. Az egyetértés szintje: $8 / 8$.

\section{A/3. Krónikus fájdalmak}

1. A természetes gyógymódok, a fizikális terápia, köztük vízi tornagyakorlatok és a termominerális vízbe merítés mérsékelhetik a fájdalmakat, ezért adjuváns alkalmazásuk ajánlott.

A bizonyitékok ereje és minösége: $2 B$. Az egyetértés szintje: $8 / 8$.

2. Lágyrész-fájdalmak és nagyízületek (váll, könyök, csukló, térd, boka) helyi gyulladásos reakciója esetén transdermalis NSAID ajánlott.

A bizonyitékok ereje és minösége: $1 A$. Az egyetértés szintje: $8 / 8$.

3. Acetaminophen választandó első peroralis gyógyszerként az enyhe fájdalmak esetén, az egyéni ellenjavallatok figyelembevételével. Májelégtelenség esetén ellenjavallt, krónikus májmúködési zavar (hepatopathia, etilabúzus stb.) mellett a tartós kezelés nem ajánlott.

A bizonyitékok ereje és minösége: $1 A$. Az egyetértés szintje: $8 / 8$. 
4. Acetaminophen és helyi NSAID-kezelések nem kielégítő hatása esetén ajánlottak a peroralis nem szelektív, illetve COX-2-gátló készítmények a lehető legkisebb adagban és legrövidebb ideig, PPI adása mellett, az egyéni kockázati tényezők figyelembevételével.

A bizonyitékok ereje és minősége: $1 A$. Az egyetértés szintje: $8 / 8$.

5. A közepes és erős fájdalmakban az NSAID gyógyszerek hatásosabbak az acetaminophen-monoterápiánál.

A bizonyitékok ereje és minósége: $1 B$. Az egyetértés szint je: $8 / 8$.

6. Rubefaciens készítmények alkalmazása elsősorban lokalizált, regionális lágyrész-fájdalmak kezelésére javasolt, gyulladt nagyízületekre nem ajánlott, lokalizált, nem gyulladásos nagyízületi fájdalom esetén lokális kapszaicinkezelés megpróbálható.

A bizonyitékok ereje és minósége: $2 B$. Az egyetértés szintje: $8 / 8$.

7. Acetilszalicilsavat szedő betegek esetében a peroralis NSAID helyett más fájdalomcsillapító ajánlott.

A bizonyitékok ereje és minösége: $1 A$. Az egyetértés szintje: $8 / 8$.

\section{A/4. Közepes és erős, kevert típusú, terápiarezisztens fájdalmak kezelésére vonatkozó ajánlások}

1. Kombinációs kezelés során sem szabad az acetaminophen és az NSAID-ok maximális napi adagját túllépni, azonban lokalizált mozgásszervi fájdalom esetén, ezen határokon belül átmenetileg helyi transdermalis NSAID-, szalicilát-, mentolkezelés megkísérelhető.

A bizonyitékok ereje és minösége: IA. Az egyetértés szintje:

2. Azoknak a közepes és erôs fájdalmaktól szenvedő betegeknek, akiknek mozgása és életminősége a fájdalom miatt nagymértékben korlátozott, s nincs egyéb, oki terápiás lehetóségre (például mútét) mód, vagy a mútétig várnia kell, opioidokkal történő fájdalomcsillapító kezelése - a haszon-kockázat alapos mérlegelése után - javasolt.

a) Az opioidterápia megkezdése előtt a beteget és hozzátartozóit részletesen tájékoztatni kell a gyógyszer tárolásával, felírásával, kiváltásával kapcsolatos ismeretekről, a gyógyszer alapvető tulajdonságairól, hatásairól, a várható mellékhatásokról, azok megelőzésének lehetőségeiről.

b) A tartós fájdalomtól szenvedók kezelésére olyan napi dózist kell biztosítani, ami a beteg önálló mozgásának és életminőségének javulását eredményezi a lehető legkevesebb mellékhatás mellett.

c) A kezelőorvosnak számolnia kell minden lehetséges mellékhatással, azokra fel kell hívnia a beteg figyelmét, a rendszeres kontrollvizsgálatok során rá kell kérdeznie, és azokat fel kell ismernie. Alapvető és kötelező a székszorulás megelőzése! d) Az opioiddal kezelt betegek esetében folyamatosan ellenőrizni kell a terápiás cél teljesülését, a biztonságos és felelős gyógyszeralkalmazást.

e) A látszólag hatástalan kezelést csak próbaelvonás után szabad beszüntetni.

f) Tartós hatású készítmények alkalmazása során számolni kell az áttörő fájdalommal és azt rövid hatású készítményekkel kell megelőzni vagy kezelni.

g) Tartós opioidterápiában részesülő betegnél számolni kell a toleranciával.

h) Természetes opiát- és metadonkezelést csak az alkalmazásában jártas orvos indíthat.

A bizonyitékok ereje és minösége: $1 A$. Az egyetértés szintje: $8 / 8$.

3. Az adjuváns gyógyszerelést a legkisebb adaggal kell kezdeni és azt fokozatosan ajánlott emelni, tartós szteroidkezelést csak az indikációjának megfelelő esetekben szabad adni a lehető legszükségesebb ideig.

A bizonyitékok ereje és minösége: $1 A$. Az egyetértés szintje: $7 / 8$.

4. A neuropathiás fájdalom esetén a megfelelő kiegészítő kezelést biztosítani kell. Lokalizált neuropathiás fájdalom esetén (például ízületeken végzett mútétek hegfájdalma) transdermalis kapszaicin- és helyi lidocainkezelés megkísérelhető.

A bizonyitékok ereje és minösége: $1 A$. Az egyetértés szintje: $8 / 8$.

5. A készítményeknek elsődlegesen monoterápiában való adása ajánlott, elfogadható azonban kombinált gyógyszeres kezelés és a nem gyógyszeres kezelés beépítése a terápiás stratégiába.

A bizonyitékok ereje és minösége: $2 B$. Az egyetértés szintje: $8 / 8$.

\section{B) AJÁNLÁSOK ÉLETKORUK, TÁRSBETEGSÉGEIK VAGY A MOZGÁSSZERVEK FOKOZOTT IGÉNYBEVÉTELE MIATT KOCKÁZATI BETEGEK GYÓGYSZERES FÁJDALOMCSILLAPÍTÁSÁRA}

\section{B/1. Idős/magas kockázati csoportba tartozó betegek gyógyszeres fájdalomcsillapító kezelésére vonatkozó ajánlások}

1. Az időskorúak ( 65 évesnél idősebbek) kockázatait az általánosnál alaposabban kell felmérni és őket fiziológiás és mentális kapacitásaikat figyelembe véve differenciáltan kell besorolni.

A bizonyitékok ereje és minösége: $1 A$. Az egyetértés szintje: $8 / 8$.

2. Az élettani mutatókon kívül a test- és ezen belül az izomtömeget, a mozgások összerendezettségét, az egyensúlyozó képességet, összességében a napi és társa- 
dalmi tevékenységek végzésének képességét egyénileg kell értékelni.

A bizonyitékok ereje és minösége: $1 A$. Az egyetértés szintje: $8 / 8$.

3. Fel kell mérni az idős beteg mentális képességeit és környezetének együttmúködési készségét a gyógyszerelési tévedések kockázatának csökkentése céljából.

A bizonyitékok ereje és minösége: $1 A$. Az egyetértés szintje: $8 / 8$.

4. Meg kell győződni arról, hogy az idős beteg ellátói tisztában vannak-e ezekkel a kockázatokkal, megkülönböztetett figyelemmel kísérik-e az idős beteget és ellátják-e a biztonságos gyógyszerszedéshez szükséges információkkal.

A bizonyitékok ereje és minösége: $1 A$. Az egyetértés szintje: $8 / 8$.

5. Nem szelektív COX-1-gátlók és COX-2-gátlók alkalmazása csak egyes biztonságos esetekben - más terápia kudarca esetén - szoros megfigyelés mellett ajánlott.

a) Hypertonia, aktív gyomorfekély, vese-, ischaemiás szívbetegség, szívelégtelenség esetén alkalmazásuk ellenjavallt.

b) Aktív vagy anamnesztikus gyomorfekély, Helicobacter pylori-infekció, szteroid vagy szelektív szerotoninreuptake-gátló kezelés esetén alkalmazásuk nem ajánlott.

c) Nem szelektív COX-gátló kezelés csak protonpumpagátló (PPI) vagy más hatásos gyomorvédelem mellett ajánlott.

d) Minden NSAID-szedő idős beteget rendszeresen ellenőrizni kell a gastrointestinalis, renalis toxicitás, hypertonia és szívelégtelenség kockázata miatt.

A bizonyitékok ereje és minösége: $1 A$. Az egyetértés szintje: $8 / 8$.

6. A megfelelő felnőttadagokat egyénileg kell a felmért kockázati besorolásnak megfelelően meghatározni és azoktól a csökkentés irányába kell eltérni. A maximális szokásos felnőtt napi adag nem léphető túl, figyelemmel kell kísérni a kombinált tabletták összetételét is.

A bizonyitékok ereje és minósége: $1 A$. Az egyetértés szintje: $8 / 8$.

7. A multimorbid, többféle gyógyszert szedő, szteroidkezelésben, antikoaguláns terápiában részesülő, krónikus máj-, vese-, gyomor- és érbetegek magasabb életkoruktól függetlenül kockázati betegnek tekintendők.

A bizonyitékok ereje és minósége: $1 A$. Az egyetértés szintje: $8 / 8$.

\section{B/2. Gyermekkorúak fájdalomcsillapító kezelésére vonatkozó ajánlások}

1. Gyermekkorúak fájdalomcsillapító kezelése - különösen az NSAID-kezelés - csak az életkorra vonatkozó törzskönyvezés és alkalmazási előírások szerint történhet.

A bizonyitékok ereje és minősége: $1 A$. Az egyetértés szintje: $8 / 8$.
2. A nem receptköteles, fájdalomcsillapítóként hirdetett NSAID-tartalmú gyógyszerek gyermekkori alkalmazása során különösen be kell tartani a hatóanyag adagolására vonatkozó szabályokat. A nem vényköteles készítmények alkalmazási előírásai és betegtájékoztatói tartalmazzák a gyermekkorúakra vonatkozó korlátozásokat. A gyermeket kezelő orvos feladata, hogy felhívja a gyermek gondozóinak figyelmét, hogy nem vényköteles készítményt csak ezek betartásával, lehetőség szerint csak az orvos konzultálásával alkalmazzanak.

A bizonyitékok ereje és minösége: $1 B$. Az egyetértés szintje: $8 / 8$.

3. A gyermek- és a felnőttkor határán lévő fiatalkorúak gyógyszerszedési fegyelme, együttmúködése fejlődési okokból sokszor nem kielégítő. A szülőknek, illetve a fiatalkorút gondozóknak - fóleg a krónikus kezelést igénylők esetében - különös figyelmet kell fordítani a gyógyszerszedési előírások betartására, a kezelőorvosnak ezt ellenőriznie kell.

$A$ bizonyitékok ereje és minősége: $2 B$. Az egyetértés szintje: $8 / 8$.

\section{B/3. Foglalkozási és sporttevékenység miatti fokozott igénybevétel okozta fájdalom csillapítására vonatkozó ajánlások}

1. A foglalkozási eredetünek tekintett mozgásszervi fájdalom azonosításához fel kell tárni az összefüggést a beteg anatómiai-alkati sajátosságai és a pontosan leírt munkamozzanatok között. Az eredményes fájdalomcsillapításhoz a bizonyított ok-okozati összefüggés kiküszöbölésére is törekedni kell.

A bizonyitékok ereje és minősége: $1 A$. Azegyetértés szintje: $8 / 8$.

2. A sportolók túlzott fizikai igénybevételéből származó fájdalmak csillapításához fel kell tárni a sportoló adottságait, edzettségét, a tartós és az aktuális terhelés (folyadékvesztés, korlátozott lebontófunkciók) szerepét a sérülés és a következményes fájdalom létrejöttében.

A bizonyitékok ereje és minösége: $1 A$. Az egyetértés szintje: $8 / 8$.

3. A versenysportolók fájdalomcsillapító gyógyszereinek megválasztásánál tájékozódni kell a tiltott gyógyszerek és vegyületek listájáról.

A bizonyitékok ereje és minősége: $1 A$. Az egyetértés szintje: $8 / 8$.

\section{A tanulmány értékelése}

A tanulmányt a megszövegezésben részt nem vevő, a szerzőktől független auditorok (B. G. és G. P.) az AGREE II. irányelv-minősítő rendszer szempontjai alapján (23 doménben a tanulmány célja, tárgya, célközönsége, módszertana, gyakorlati alkalmazhatósága, az irodalomkutatás, a bizonyítékok ereje és súlya, várható hatása és összesítő értékelése 0-7 pontos skálán) átlagosan 6,5 ponttal (95\%) értékelték. 
Anyagi támogatás: A szerzők a tanulmány témájával kapcsolatosan a Sager Pharma Kft. megbízásából díjazott szakértői tevékenységet végeztek.

Szerzői munkamegosztás: H. L.: Szerkesztés. Az alkalmazás szakmai célcsoportjai; A nociceptív fájdalom és a nem szteroid gyulladáscsökkentők hatásmechanizmusa; A regionális mozgásszervi szindrómák jelentkezésének kitett kockázati betegcsoportok; A nem szteroid gyulladáscsökkentő készítmények hatásosságának meghatározó tényezői; A nem szteroid gyulladáscsökkentők potenciális nem kívánt hatásainak kitett kockázati betegcsoportok; Ajánlások regionális nociceptív eredetü mozgásszervi fájdalmak nem szteroid gyulladáscsökkentőkkel történő fájdalomcsillapító gyógyszeres kezeléséhez fejezetek. B. G.: Belső auditor. Ajánlások regionális nociceptív eredetû́ mozgásszervi fájdalmak nem szteroid gyulladáscsökkentőkkel történő fájdalomcsillapító gyógyszeres kezeléséhez fejezet. B. E.: A multidiszciplináris szemléletü fájdalomambulanciák lehetőségei a krónikus, regionális mozgásszervi fájdalom ellátásában; Ajánlások regionális nociceptív eredetű mozgásszervi fájdalmak nem szteroid gyulladáscsökkentőkkel történő fájdalomcsillapító gyógyszeres kezeléséhez fejezetek. G. P.: Belső auditor. Ajánlások regionális nociceptív eredetü mozgásszervi fájdalmak nem szteroid gyulladáscsökkentőkkel történő fájdalomcsillapító gyógyszeres kezeléséhez fejezet. P. R.: A nem szteroid gyulladáscsökkentő készítmények hatásosságának meghatározó tényezői; Az oralis, parenteralis és transdermalis gyógyszerbevitel sajátosságai; Ajánlások regionális nociceptív eredetű mozgásszervi fájdalmak nem szteroid gyulladáscsökkentőkkel történő fájdalomcsillapító gyógyszeres kezeléséhez fejezetek. S. P.: A tanulmány által lefedett klinikai képek. A regionális mozgásszervi szindrómák jelentkezésének kitett kockázati betegcsoportok (Amatőr és versenysportolók mozgásszervi eredetű fájdalmi szindrómái); Ajánlások regionális nociceptív eredetû mozgásszervi fájdalmak nem szteroid gyulladáscsökkentőkkel történő fájdalomcsillapító gyógyszeres kezeléséhez fejezetek. Sz. S.: A nem szteroid gyulladáscsökkentők biztonságossága; Ajánlások regionális nociceptív eredetű mozgásszervi fájdalmak nem szteroid gyulladáscsökkentőkkel történő fájdalomcsillapító gyógyszeres kezeléséhez fejezetek. V. E.: A tanulmány által lefedett klinikai képek. A nociceptív fájdalom és a nem szteroid gyulladáscsökkentők hatásmechanizmusa; A regionális mozgásszervi szindrómák jelentkezésének kitett kockázati betegcsoportok (A foglalkozással összefüggő regionális mozgásszervi fájdalmi szindrómák); A nem szteroid gyulladáscsökkentő készítmények hatásosságának meghatározó tényezői; $\mathrm{Az}$ oralis, parenteralis és transdermalis gyógyszerbevitel sajátosságai; A nem szteroid gyulladáscsökkentők biztonságossága; Ajánlások regionális nociceptív eredetú mozgásszervi fájdalmak nem szteroid gyulladáscsökken- tőkkel történő fájdalomcsillapító gyógyszeres kezeléséhez fejezetek.

A tanulmány végleges változatát valamennyi szerző elolvasta és jóváhagyta.

Érdekeltségek: A szerzőknek nincsenek érdekeltségeik.

\section{Irodalom}

[1] WHO Handbook for guideline development, March 2014.

[2] Guyatt GH, Oxman AD, Vist GE, et al. GRADE: an emerging consensus on rating quality of evidence and strength of recommendations. BMJ 2008; 336: 924-926.

[3] Guyatt GH, Oxman AD, Aki EA, et al. GRADE guidelines: 1. Introduction - GRADE evidence profiles and summary of findings tables. J Clin Epidemiol. 2011; 64: 383-394.

[4] National Collaborating Centre for Methods and Tools (2011). Critically appraising practice guidelines: The AGREE II instrument. McMaster University, Hamilton, ON. (Updated 12 September, 2017). Retrieved from: http://www.nccmt.ca/ knowledge-repositories/search/100

[5] Generaal E, Vogelzangs N, Macfarlane GJ, et al. Biological stress systems, adverse life events and the onset of chronic multisite musculoskeletal pain: a 6-year cohort study. Ann Rheum Dis. 2016; 75: 847-854.

[6] Voscopoulos C, Lema M. When does acute pain become chronic? Br J Anaesth. 2010; 105(Suppl 1): i69-i85.

[7] Ossipov MH, Dussor GO, Porreca F. Central modulation of pain. J Clin Invest. 2010; 120: 3779-3787.

[8] Tracey I, Mantyh PW. The cerebral signature for pain perception and its modulation. Neuron 2007; 55: 377-391.

[9] Amaya F, Izumi Y, Matsuda M, et al. Tissue injury and related mediators of pain exacerbation. Curr Neuropharmacol. 2013; 11: 592-597.

[10] Cohen SP, Mao J. Neuropathic pain: mechanisms and their clinical implications. BMJ 2014; 348: 1756-1768.

[11] Riccioti E, Fitzgerald GA. Prostaglandins and inflammation. Arterioscler Thromb Vasc Biol. 2011; 31: 986-1000.

[12] Simmons DL, Botting RM, Hla T. Cyclooxigenase isozymes: the biology of prostaglandin synthesis and inhibition. Pharmacol Rev. 2004; 56: 367-436.

[13] Poór Gy. (ed.) Rheumatology. [Reumatológia.] Medicina Könyvkiadó, Budapest, 2008. [Hungarian]

[14] Mester Á. Opportunities of magnetic resonance imaging in the diagnostics of musculoskeletal diseases. [A mágneses rezonanciás vizsgálatok lehetőségei a musculoskeletalis diagnosztikában.] LAM 2004; 14: 771-779. [Hungarian]

[15] Ungváry Gy. Health care for occupational diseases. [Munkaegészségtan.] Medicina Könyvkiadó, Budapest 2004; pp. 686694. [Hungarian]

[16] Kellgren JH, Lawrence JS. Rheumatism in miners. Part II: Xray study. Br J Ind Med. 1952; 9: 197-207.

[17] Björkstén MG, Boquist B, Talbäck M, et al. Neck and shoulder ailments in a group of female industrial workers with monotonous work. Ann Occup Hyg. 1996; 40: 661-673.

[18] Caplan PS, Freedman LM, Conelly TP. Degenerative joint disease of the lumbar spine in coal miners - a clinical and X-ray study. Arthritis Rheum. 1996; 9: 693-702.

[19] Zejda JE, Gaździk TS, Czekaj I. Low back pain syndrome in coal miners: preliminary results of an epidemiological study. Med Pr. 1998; 49: 353-361. 
[20] Latza U, Karmaus W, Stürmer T, et al. Cohort study of occupational risk factors of low back pain in construction workers. Occup Environ Med. 2000; 57: 28-34.

[21] Snook SH. Work-related low back pain: secondary intervention. J Electromyogr Kinesiol. 2004; 14: 153-160.

[22] Magnavita N, Elovaino M, De Nardis I, et al. Environmental discomfort and musculoskeletal disorders. Occup Med. (Lond.) 2011; 61: 196-201.

[23] Pienimäki T. Cold exposure and musculoskeletal disorders and diseases. A review. Int J Circumpolar Health 2002; 61: 173182

[24] Dovrat E, Katz-Leurer M. Cold exposure and low back pain in store workers in Israel. Am J Int Med. 2007; 50: 626-631.

[25] Staal JB, Hlobil H, van Tulder MW, et al. Occupational health guidelines for the management of low back pain: an international comparison. Occup Environ Med. 2003; 60: 618-626.

[26] Vereckei E, Susanszky E, Kopp M, et al. Psychosocial, educational, and somatic factors in chronic nonspecific low back pain. Rheumatol Int. 2013; 33: 587-592.

[27] Madden CC, Putukian M, Young CC, et al. (eds.) Sports pharmacology of pain and inflammation control in athletes. In: Netter's sportsmedicine. Saunders, Elsevier, Philadelphia, 2010; pp. 47-51, 171-183.

[28] Feucht CL, Patel DR. Analgesics and anti-inflammatory medications in sports: use and abuse. Pediatr Clin North Am. 2010; 57: 751-774

[29] Lippi G, Franchini M, Guidi GC. Non steroidal anti-inflammatory drugs (NSAIDs) in athletes. Br J Sports Med. 2006; 40: 661-663.

[30] The World Anti-Doping Code. The 2010 Prohibited List. International Standard. WADA website

[31] Rheumatology and Physiotherapy Board. Analgetic and antiinflammatory drug treatment of rheumatologic diseases. Guideline of the Ministry of Health Care (invalid). [Reumatológiai és Fizioterápiás Szakmai Kollégium. A gyógyszeres fájdalomcsillapításról és gyulladásgátlásról a reumatológiai betegségekben. $\mathrm{Az}$ Egészségügyi Minisztérium szakmai protokollja (hatályon kívül helyezve).] Egészségügyi Közlöny 2005; 21: 3532-3541. [Hungarian]

[32] Assessment and management of chronic pain. Health Care Guideline Institute for Clinical Systems Improvement, 2013. www.icsi.org

[33] Myers J, Wielage RC, Han B, et al. The efficacy of duloxetine, non-steroidal anti-inflammatory drugs, and opioids in osteoarthritis: a systematic literature review and meta-analysis. BMC Musculoskelet Disord. 2014, 15: 76-100.

[34] Trescot AM, Datta S, Lee M, et al. Opioid pharmacology. Pain Physician 2008; 11 (2 Suppl): S133-S153.

[35] Dworkin RH, O'Connor AB, Audette J, et al. Recommendations for the pharmacological management of neuropathic pain: An overview and literature update. Mayo Clin Proc. 2010; 85(3 Suppl): S3-S14.

[36] Derry S, Conaghan P, Da Silva JA, et al. Topical NSAIDs for chronic musculoskeletal pain in adults. Cochrane Database of Systematic Reviews 2016; 4: CD007400.

[37] Rannou F, Pelletier JP, Martel-Pelletier J. Efficacy and safety of topical NSAIDs in the management of osteoarthritis: Evidence from real-life setting trials and surveys. Semin Arthritis Rheum. 2016; 45(4 Suppl): S18-S21.

[38] Szamosi Sz. Application of topical application of non-steroidal antiinflammatory drugs for pain relief in rheumatology. [A topikus nem szteroid gyulladásgátló helye a reumatológiai fájdalomcsillapításban.] Magy Reumatol. 2017; 58: 20-24. [Hungarian]

[39] Hochberg MC, Altman RC, April KT, et al. American College of Rheumatology 2012 recommendations for the use of nonpharmacologic and pharmacologic therapies in osteoarthritis of the hand, hip, and knee. Arthritis Care Res. 2012; 64: 465474.

[40] Järvinen TA. Muscle injuries: optimising recovery. Best Pract Res Clin Rheumatol. 2007; 21: 317-331.

[41] Haroutiunian S, Drennan DA, Lipman AG. Topical NSAID therapy for musculoskeletal pain. Pain Med. 2010; 11: 535549.

[42] Mazières B, Rouanet S, Guillon Y, et al. Topical ketoprofen patch in the treatment of tendinitis: a randomized, doubleblind, placebo controlled study. J Rheumatol. 2005; 32: 15631670.

[43] Mazières B, Rouanet S, Velicy J, et al. Topical ketoprofen patch $(100 \mathrm{mg})$ for the treatment of ankle sprain: a randomized, double-blind, placebo-controlled study. Am J Sports Med. 2005; 33: 515-523.

[44] Moore RA, Tramer MR, Carroll D. Quantitative systematic review of topically applied NSAIDs. BMJ 1998; 316: 333338.

[45] Mehallo CJ, Drezner JA, Bytomski JR. Practical management: NSAIDs use in athletic injuries. Clin J Sport Med. 2006; 16: 170-174.

[46] Dahners LE, Gilbert JA, Lester GE, et al. The effect of a nonsteroidal antiinflammatory drug on the healing of ligaments. Am J Sports Med. 1988; 16: 641-646.

[47] Elder CL, Dahners LE, Weinhold PD. A Cox-2 inhibitor impairs ligament healing in the rat. Am J Sports Med. 2001; 29: 801-805.

[48] Moorman CT, Kukreti U, Fenton DC. The early effect of ibuprofen on the mechanical properties of healing medial collateral ligament. Am J Sports Med. 1999; 27: 738-741.

[49] Andres BM, Murrell GA. Treatment of tendinopathy: what works, what does not, and what is on the horizon. Clin Orthop Relat Res. 2008; 466: 1539-1554.

[50] Marsolais D, Coté CH, Frenetta J. NSAIDs reduce neutrophil and macrophage accumulation but does not improve tendon regeneration. Lab Invest. 2003; 83: 991-999.

[51] Petri M, Hufman SL, Waser G, et al. Celecoxib effectively treats patients with acute shoulder tendonitis/bursitis. J Rheumatol. 2004; 31: 258-260.

[52] Lanier $\mathrm{AB}$. Use of nonsteroidal anti-inflammatory drugs following exercise induced muscle injury. Sports Med. 2003; 33: 177-186.

[53] Osterwalder A, Reiner V, Reiner G, et al. Tissue absorption and distribution of ketoprofen after patch application in subject undergoing knee arthroscopy or endoscopic carpal ligament release. Arzneimittelforschung 2002; 52: 822-827.

[54] Rolf C, Movin T, Engstrom B, et al. An open, randomized study of ketoprofen in patients surgery for Achilles or patellar tendinopathy. J Rheumatol. 1997; 24: 1595-1598.

[55] Rolf C, Engström B, Beauchard C, et al. Intra-articular absorption and distribution of ketoprofen after topical plaster application and oral intake in 100 patients undergoing knee arthroscopy. Rheumatology 1999; 38: 564-567.

[56] Larson CM, Almekinders LC, Karas SG, et al. Evaluating and managing muscle contusions and myositis ossificans. Phys Sports Med. 2002; 30: 41-46.

[57] Kumaresan C. S+ ibuprofen (dexibuprofen): the superior non steroidal anti-inflammatory agents for development of pharmaceuticals. Int J Curr Pharm Res. 2010; 2(3): 1-3.

[58] Warner TD, Giuliano F, Vojnovic I. et al. Nonsteroid drug selectivities for cyclo-oxygenase- 1 rather than cyclo-oxygenase- 2 are associated with human gastrointestinal toxicity. A full in vitro analysis. Proc Natl Acad Sci USA 1999; 96: 7563-7568.

[59] Szekanecz Z. Questions and answers on the non-steroidal antinflammatory drugs and cylo-oxygenase-2 inhibitors. [Kérdések és válaszok a nem szteroid gyulladáscsökkentőkról és a 
COX-2-gátlókról.] Háziorvosi Továbbképző Szemle 2003; 8: 590-594. [Hungarian]

[60] Gachályi B. Introduction into clinical pharmacology. [Bevezetés a klinikai farmakológiába.] Springer Hungarica, Budapest, 1992; pp. 25-73. [Hungarian]

[61] FDA Draft guidance on menthol, methyl salicylate. Revised 2016. https://www.fda.gov/downloads/Drugs/Guidance ComplianceRegulatoryInformation/Guidances/UCM 406333.pdf

[62] McAlindon TE, Bannuru RR, Sullivan MC, et al. OARSI guidelines for the non-surgical management of knee osteoarthritis. Osteoarthritis Cartilage 2014; 22: 363-388.

[63] Martin D, Valdez J, Boren J, et al. Dermal absorption of camphor, menthol, and methyl salicylate in humans. J Clin Pharmacol. 2004; 44: 1151-1157.

[64] Higashi Y, Kiuchi T, Furuta K. Efficacy and safety profile of a topical methyl salicylate and menthol patch in adult patients with mild to moderate muscle strain: A randomized, doubleblind, parallel-group, placebo-controlled, multicenter study. Clin Ther. 2010; 32: 34-43

[65] Yano T, Nakagawa A, Tsuji M, et al. Skin permeability of various non-steroidal anti-inflammatory drugs in man. Life Sci. 1986; 39: 1043-1050.

[66] Sekiya I, Morito T, Hara K, et al. Ketoprofen absorption by muscle and tendon after topical or oral administration in patients undergoing anterior cruciate ligament reconstruction. AAPS Pharm Sci Tech. 2010; 11: 154-158.

[67] Papp R, Bálint G. Investigation of effectivity, tolerability and patient compliance of KEPLAT ${ }^{\circledR} 20 \mathrm{mg}$ drug patch in patients with acute musculoskeletal complaints. [KEPLAT ${ }^{\circledR} 20 \mathrm{mg}$ gyógyszeres tapasz hatásosságának, tolerálhatóságának és a beteg együttmúköódésének vizsgálata akut mozgásszervi betegeknél.] Magy Reumatol. 2013; 54: 183-187. [Hungarian]

[68] Fine PG. Treatment guidelines for the pharmacological management of pain in older persons. Pain Med. 2012; 13: S57S66.

[69] Park KE, Qin Y, Bavry AA. Nonsteroidal anti-inflammatory drugs and their effects in the elderly. Aging Health 2012; 8: 167-177.

[70] Taylor R Jr, Lemtouni S, Weiss K, et al. Pain management in the elderly: an FDA safe use initiative expert panel's view on preventable harm associated with NSAID therapy. Curr Gerontol Geriatr Res. 2012; 2012: Article ID 196159.

[71] Recommendations for FDA interventions to decrease the occurrence of acetaminophen hepatotoxicity 2008. www.fda. gov/Guidances/UCM164098

[72] Gazarian M, Graudins LV. Safe use of non-steroidal anti-inflammatory drugs in infants and children. Med Today 2006; 7: $71-73$.

[73] Information on paediatric rheumatic disease. Drug therapy. [Tájékoztatás a gyermekkori reumás megbetegedésekról. Gyógyszeres kezelés.] Available from: https://www.printo.it/ pediatric- rheumatology/HU/info/15/ [Hungarian]

[74] Lewis SR, Nicholson A, Cardwell ME, et al. Nonsteroidal antiinflammatory drugs and perioperative bleeding in paediatric tonsillectomy. Cochrane Database Syst Rev. 2013; 7 : CD003591.

[75] Levy DM, Imundo LF. Nonsteroidal anti-inflammatory drugs: a survey of practices and concerns of pediatric medical and surgical specialists and a summary of available safety data. Pediatr Rheumatol Online J. 2010; 8: 7 .

[76] Hernández-Díaz S, Rodríguez LA. Association between nonsteroidal antiinflammatory drugs and upper gastrointestinal tract bleeding/perforation: an overview of epidemiologic studies published in the 1990s. Arch Intern Med. 2000; 160: 2093-2099.
[77] Solomon SD, Pfeffer MA, McMurray JJ, et al. Effect of celecoxib on cardiovascular events and blood pressure in two trials for the prevention of colorectal adenomas. Circulation 2006; 114: 1028-1235

[78] Antman EM, Bennett JS, Daugherty A, et al. Use of nonsteroidal antiinflammatory drugs. An update for clinicians: a scientific statement from the American Heart Association. Circulation 2006; 115: 1634-1642.

[79] Lanas A, Garcia-Tell G, Armada B, et al. Prescription pattern and appropriateness of NSAID therapy according to gastrointestinal risk and cardiovascular history in patients with diagnoses of osteoarthritis. BMC Med. 2011; 9: 38

[80] Valkhoff VE, van Soest EM, Sturkenboom MC, et al. Timetrends in gastroprotection with nonsteroidal anti-inflammatory drugs (NSAIDs). Aliment Pharmacol Ther. 2010; 31: 12181228 .

[81] Abraham NS, El-Serag HB, Johnson ML, et al. National adherence to evidence-based guidelines for the prescription of nonsteroidal anti-inflammatory drugs. Gastroenterology 2005; 129: 1171-1118.

[82] Bhala N, Emberson J, Merhi A, et al., Coxib and traditional NSAID Trialists' (CNT) Collaboration. Vascular and upper gastrointestinal effects of non-steroidal anti-inflammatory drugs: meta-analyses of individual participant data from randomised trials. Lancet 2013; 382: 769-779.

[83] Gislason GH, Jacobsen S, Rasmussen JN, et al. Risk of death or reinfarction associated with the use of selective cyclooxygenase- 2 inhibitors and nonselective nonsteroidal antiinflammatory drugs after acute myocardial infarction. Circulation 2006; 113: 2906-2913.

[84] Schjerning OA, Fosbol EL, Lindharsen J, et al. Duration of treatment with nonsteroidal anti-inflammatory drugs and impact on risk of death and recurrent myocardial infarction in patients with prior myocardial infarction: a nationwide cohort study. Circulation 2011; 123: 2226-2235.

[85] Olsen AM, Fosbol EL, Lindhardsen J, et al. Long-term cardiovascular risk of nonsteroidal anti-inflammatory drug use according to time passed after first-time myocardial infarction: a nationwide cohort study. Circulation 2012; 126: 1955-1963.

[86] Perry LA, Mosler C, Atkins A, et al. Cardiovascular risk associated with NSAIDs and COX-2 inhibitors. US Pharm. 2014; 39: $35-38$

[87] European Medicines Agency. Updated advice on use of highdose ibuprofen. EMA 325007/2015. 22 May 2015.

[88] Schjerning Olsen AM, Fosbøl EL, Gislason GH. The impact of NSAID treatment on cardiovascular risk - on sight of Danish observational data. Basic Clin Pharmacol Toxicol. 2014; 115: 179-184.

[89] Becker MC, Wang TH, Wisniewski L, et al. Rationale, design, and governance of Prospective Randomized Evaluation of Celecoxib Integrated Safety versus Ibuprofen Or Naproxen (PRECISION), a cardiovascular end point trial of nonsteroidal antiinflammatory agents in patients with arthritis. Am Heart J. 2009; 157: 606-612.

[90] Bello AE, Holt JR. Cardiovascular risk with non-steroidal antiinflammatory drugs: clinical implications. Drug Saf. 2014; 37: 897-902.

[91] Horváth VJ, Tabák GÁ, Szabó G, et al. Cardiovascular side effects of non-steroidal anti-inflammatory drugs in the light of recent recommendations. Diclofenac is not more dangerous. [A nem szteroid gyulladásgátló készítmények cardiovascularis mellékhatásai a legújabb ajánlások fényében. Nem veszélyesebb a diclofenac.] Orv Hetil. 2015; 156: 516-520. [Hungarian]

[92] Haag MD, Bos MJ, Hofman A, et al. Cyclooxygenase selectivity of nonsteroidal anti inflammatory drugs and risk of stroke. Arch Intern Med. 2008; 168: 1219-1224. 
[93] Barthelemy O, Limbourg T, Collet JP, et al. Impact of nonsteroidal anti-inflammatory drugs (NSAIDs) on cardiovascular outcomes in patients with stable atherothrombosis or multiple risk factors. Int J Cardiol. 2013; 163: 266-271.

[94] Mamdani M, Juurlink DN, Lee DS, et al. Cyclo-oxygenase-2 inhibitors versus non-selective non-steroidal anti-inflammatory drugs and congestive heart failure outcomes in elderly patients: a population-based cohort study. Lancet 2004; 363: $1751-1756$

[95] Feenstra J, Heerdink ER, Grobbee DE, et al. Association of nonsteroidal anti inflammatory drugs with first occurrence of heart failure and with relapsing heart failure: the Rotterdam Study. Arch Intern Med. 2002; 162: 265-270.

[96] Page J, Henry D. Consumption of NSAIDs and the development of congestive heart failure in elderly patients: an underrecognized public health problem. Arch Intern Med. 2000 160: $777-784$.

[97] Gislason GH, Rasmussen JN, Abildstrom SZ, et al. Increased mortality and cardiovascular morbidity associated with use of nonsteroidal anti-inflammatory drugs in chronic heart failure. Arch Intern Med. 2009; 169: 141-149.

[98] Johnson AG, Nguyen TV, Day RO. Do nonsteroidal anti-inflammatory drugs affect blood pressure? A meta-analysis. Ann Intern Med. 1994; 121: 289-300.

[99] Krum H, Swergold G, Curtis SP, et al. Factors associated with blood pressure changes in patients receiving diclofenac or etoricoxib: results from the MEDAL study. J Hypertens. 2009; 27: 886-893.

[100] Chrischilles EA, Wallace RB. Nonsteroidal anti-inflammatory drugs and blood pressure in an elderly population. J Gerontol. 1993; 48: M91-M96.

[101] Sowers JR, White WB, Pitt B, et al. The effects of cyclooxygenase- 2 inhibitors and nonsteroidal anti-inflammatory therapy on 24-hour blood pressure in patients with hypertension, osteoarthritis, and type 2 diabetes mellitus. Arch Intern Med. 2005; 165: 161-168.

[102] Whelton A, White WB, Bello AE, et al. Effects of celecoxib and rofecoxib on blood pressure and edema in patients $\geq 65$ years of age with systemic hypertension and osteoarthritis Am J Cardiol. 2002; 90: 959-963.

[103] Chao TF, Liu CJ, Chen SJ, et al. The association between the use of non-steroidal anti-inflammatory drugs and atrial fibrillation: a nationwide case-control study. Int J Cardiol. 2013; 168: 312-316.

[104] Liu G, Yan YP, Zheng XX, et al. Meta-analysis of nonsteroidal anti-inflammatory drug use and risk of atrial fibrillation. Am J Cardiol. 2014; 114: 1523-1529.

[105] Schmidt M, Christiansen CF, Mehnert F, et al. Non-steroidal anti-inflammatory drug use and risk of atrial fibrillation or flutter: population based case-control study. BMJ 2011; 343: d3450.

[106] Cheema AA. Should people on aspirin avoid ibuprofen? A review of the literature. Cardiol Rev. 2004; 12: 174-176.

[107] Catella-Lawson F, Reilly MP, Kapoor SC, et al. Cyclooxygenase inhibitors and the antiplatelet effects of aspirin. $\mathrm{N}$ Eng J Med. 2001; 345: 1809-1817.

[108] Kurth T, Glynn RJ, Walker AM, et al. Inhibition of clinical benefits of aspirin on first myocardial infarction by nonsteroidal antiinflammatory drugs. Circulation 2003; 108: 11911195

[109] Ouellet M, Riendeau D, Percival MD. A high level of cyclooxygenase-2 inhibitor selectivity is associated with a reduced interference of platelet cyclooxygenase- 1 inactivation by aspirin. Proc Natl Acad Sci USA 2001; 98: 14583-14588.

[110] Renda G, Tacconelli S, Capone ML, et al. Celecoxib, ibuprofen, and the antiplatelet effect of aspirin in patients with os- teoarthritis and ischemic heart disease. Clin Pharmacol Ther. 2006; 80: 264-274.

[111] Wilcox CM, Allison J, Benzuly K, et al. Consensus development conference on the use of nonsteroidal anti-inflammatory agents, including cyclooxygenase- 2 enzyme inhibitors and aspirin. Clin Gastroenterol Hepatol. 2006; 4: 1082-1089.

[112] Ofman JJ, MacLean CH, Straus WL, et al. A metaanalysis of severe upper gastrointestinal complications of nonsteroidal antiinflammatory drugs. J Rheumatol. 2002; 29: 804-812.

[113] Lanas A, Perez-Aisa MA, Feu F, et al. A nationwide study of mortality associated with hospital admission due to severe gastrointestinal events and those associated with nonsteroidal antiinflammatory drug use. Am J Gastroenterol. 2005; 100: $1685-1693$.

[114] Wheatley KE, Snyman JH, Brearley S, et al. Mortality in patients with bleeding peptic ulcer when those aged 60 or over are operated on early. BMJ 1990; 301: 272.

[115] Rockall TA. Management and outcome of patients undergoing surgery after acute upper gastrointestinal haemorrhage. Steering Group for the National Audit of Acute Upper Gastrointestinal Haemorrhage. J R Soc Med. 1998; 91: 518523.

[116] Castellsague J, Riera-Guardia N, Calingaert B, et al. Individual NSAIDs and upper gastrointestinal complications: a systematic review and meta-analysis of observational studies (the SOS project). Drug Saf. 2012; 35: 1127-1146.

[117] Knijff-Dutmer EA, Schut GA, van de Laar MA. Concomitant coumarin-NSAID therapy and risk for bleeding. Ann Pharmacother. 2003; 37: 12-16.

[118] Davidson BL, Verheijen S, Lensing AW, et al. Bleeding risk of patients with acute venous thromboembolism taking nonsteroidal anti-inflammatory drugs or aspirin. JAMA Intern Med. 2014; 174: 947-953.

[119] Hylek EM, Held C, Alexander JH, et al. Major bleeding in patients with atrial fibrillation receiving apixaban or warfarin: The ARISTOTLE Trial (Apixaban for Reduction in Stroke and Other Thromboembolic Events in Atrial Fibrillation): Predictors, characteristics, and clinical outcomes. J Am Coll Cardiol. 2014; 63: 2141-2147.

[120] Lanas A, Garcia-Rodriguez LA, Polo-Tomás M, et al. Time trends and impact of upper and lower gastrointestinal bleeding and perforation in clinical practice. Am J Gastroenterol. 2009; 104: 1633-1641.

[121] Fujimori S, Gudis K, Takahashi Y, et al. Distribution of small intestinal mucosal injuries as a result of NSAID administration. Eur J Clin Invest. 2010; 40: 504-510.

[122] Lombardo L, Foti M, Ruggia O, Chiecchio A. Increased incidence of small intestinal bacterial overgrowth during proton pump inhibitor therapy. Clin Gastroenterol Hepatol. 2010; 8: 504-508.

[123] Laine L, Smith R, Min K, et al. Systematic review: the lower gastrointestinal adverse effects of non-steroidal anti-inflammatory drugs. Aliment Pharmacol Ther. 2006; 24: 751-767.

[124] Goldstein JL, Eisen GM, Lewis B, et al. Video capsule endoscopy to prospectively assess small bowel injury with celecox$\mathrm{ib}$, naproxen plus omeprazole, and placebo. Clin Gastroenterol Hepatol. 2005; 3: 133-141.

[125] Szekanecz Z, Kerekes G, Soltész P. Vascular effects of biologic agents in RA and spondyloarthropathies. Nat Rev Rheumatol. 2009; 5: 677-684.

[126] Roubille C, Richer V, Starnino T, et al. The effects of tumour necrosis factor inhibitors, methotrexate, non-steroidal antiinflammatory drugs and corticosteroids on cardiovascular events in rheumatoid arthritis, psoriasis and psoriatic arthritis: a systematic review and meta-analysis. Ann Rheum Dis. 2015; 74: 480-489. 
[127] Tsai WC, Ou TT, Yen JH, et al. Long-term frequent use of non-steroidal anti-inflammatory drugs might protect patients with ankylosing spondylitis from cardiovascular diseases: a nationwide case-control study. PLoS One 2015; 10: $\mathrm{e} 0126347$.

[128] Lanas A, Tornero J, Zamorano J. Assessment of gastrointestinal and cardiovascular risk in patients with osteoarthritis who require NSAIDs: the LOGICA study. Ann Rheum Dis. 2010; 69: 1453-1458.

[129] Abdel Shaheed C, Maher CG, Williams KA, et al. Interventions available over the counter and advice for acute low back pain: systematic review and meta-analysis. J Pain 2014; 15 : $2-15$.

[130] Osteoarthritis: Care and management in adults. NICE clinical guideline [CG177]. Issued: February 2014. guidance. nice.org.uk $/ \operatorname{cg} 177$

[131] Sinusas K. Osteoarthritis: diagnosis and treatment. Am Fam Physician 2012; 85: 49-56.

[132] Blondell RD, Azadfard M, Wisniewski AM. Pharmacologic therapy for acute pain. Am Fam Physician 2013; 87: 766772 .
[133] Qaseem A, Wilt TJ, McLean RM, et al., for the Clinical Guidelines Committee of the American College of Physicians. Noninvasive treatments for acute, subacute, and chronic low back pain: A Clinical Practice Guideline from the American College of Physicians. Ann Intern Med. 2017; 166: 514-530.

[134] Chou R, Deyo R, Friedly J, et al. Systemic pharmacologic therapies for low back pain: A systematic review for an American College of Physicians Clinical Practice Guideline. Ann Intern Med. 2017; 166: 480-492.

[135] Bruyére O, Cooper C, Pelletier JP, et al. A consensus statement on the European Society for Clinical and Economic Aspects of Osteoporosis and Osteoarthritis (ESCEO) algorithm for the management of knee osteoarthritis - From evidence-based medicine to real-life setting. Semin Arthritis Rheum. 2016; 45(4 Suppl): S3-S11.

[136] Derry S, Moore RA, Gaskell H, et al. Topical NSAIDs for acute musculoskeletal pain in adults. Cochrane Database Syst Rev. 2015; 6: CD007402.

(Hodinka László dr., e-mail: hodinka.laszlo@orfi.hu) 